\title{
Estradiol Increases Glutamate and GABA Neurotransmission into GnRH Neurons via Retrograde NO-Signaling in Proestrous Mice during the Positive Estradiol Feedback Period
}

\author{
(DImre Farkas, ${ }^{1,2^{*}}$ Flóra Bálint, ${ }^{1,3^{*}}$ Erzsébet Farkas, ${ }^{4}$ Csaba Vastagh, ${ }^{1}$ Csaba Fekete, ${ }^{4,5}$ and (D) Zsolt \\ Liposits ${ }^{1,6}$
}

\section{DOI:http://dx.doi.org/10.1523/ENEURO.0057-18.2018}

${ }^{1}$ Laboratory of Endocrine Neurobiology, Institute of Experimental Medicine, Hungarian Academy of Sciences, Budapest $\mathrm{H}-1083$, Hungary, ${ }^{2}$ Laboratory of Reproductive Neurobiology, Institute of Experimental Medicine, Hungarian Academy of Sciences, Budapest H-1083, Hungary, ${ }^{3}$ Roska Tamás Doctoral School of Sciences and Technology, Faculty of Information Technology and Bionics, Pázmány Péter Catholic University, Budapest $\mathrm{H}-1083$, Hungary, ${ }^{4}$ Laboratory of Integrative Neuroendocrinology, Institute of Experimental Medicine, Hungarian Academy of Sciences, Budapest $\mathrm{H}-1083$, Hungary, ${ }^{5}$ Division of Endocrinology, Diabetes and Metabolism, Department of Medicine, Tupper Research Institute, Tufts Medical Center, Boston, MA 02111, ${ }^{6}$ Department of Neuroscience, Faculty of Information Technology and Bionics, Pázmány Péter Catholic University, Budapest H-1083, Hungary

\begin{abstract}
Surge release of gonadotropin-releasing hormone $(\mathrm{GnRH})$ is essential in the activation of pituitary gonadal unit at proestrus afternoon preceded by the rise of serum $17 \beta$-estradiol (E2) level during positive feedback period. Here, we describe a mechanism of positive estradiol feedback regulation acting directly on $\mathrm{GnRH}$-green fluorescent protein (GFP) neurons of mice. Whole-cell clamp and loose patch recordings revealed that a high physiological dose of estradiol $(200 \mathrm{pM})$, significantly increased firing rate at proestrus afternoon. The mPSC frequency at proestrus afternoon also increased, whereas it decreased at metestrus afternoon and had no effect at proestrus morning. Inhibition of the estrogen receptor $\beta(E R \beta)$, intracellular blockade of the Src kinase and phosphatidylinositol 3 kinase (PI3K) and scavenge of nitric oxide (NO) inside $\mathrm{GnRH}$ neurons prevented the facilitatory estradiol effect indicating involvement of the $\mathrm{ER} \beta / \mathrm{Src} / \mathrm{PI} / 3 \mathrm{~K} / \mathrm{Akt} / \mathrm{nNOS}$ pathway in this fast, direct stimulatory effect. Immunohistochemistry localized soluble guanylate cyclase, the main NO receptor, in both glutamatergic and GABAergic terminals innervating $\mathrm{GnRH}$ neurons. Accordingly, estradiol facilitated neurotransmissions to $\mathrm{GnRH}$ neurons via both $G_{A B A}-R$ and glutamate/AMPA/kainate-R. These results indicate that estradiol acts directly on $\mathrm{GnRH}$ neurons via the $\mathrm{ER} \beta / \mathrm{Akt} / \mathrm{nNOS}$ pathway at proestrus afternoon generating NO that retrogradely acceler-
\end{abstract}

\section{Significance Statement}

One of the major reasons of infertility is the failure in ovulation. Therefore, understanding of the neuronal processes resulting in proper ovulation is indispensable. Although hypothalamic gonadotropin-releasing hormone $(\mathrm{GnRH})$ neurons are regarded the master-neurons orchestrating reproduction, most of the relevant papers have suggested so far that the estradiol positive feedback (indispensable for ovulation) acts in these neurons mostly indirectly, via hypothalamic nuclei free of GnRH neurons. Now we have presented strong evidence that estradiol exerts fast direct stimulatory action in $\mathrm{GnRH}$ neurons during the positive feedback, by activating retrograde nitric oxide (NO) signaling to accelerate excitatory synaptic inputs to $\mathrm{GnRH}$ neurons. In addition, we suggest a putative mechanism, whereby indirect and direct actions of estradiol can work in concert regulating $\mathrm{GnRH}$ neurons. 
ates GABA and glutamate release from the presynaptic terminals contacting GnRH neurons. The newly explored mechanism might contribute to the regulation of the $\mathrm{GnRH}$ surge, a fundamental prerequisite of the ovulation.

Key words: GABA; glutamate; GnRH neuron; positive estradiol feedback; retrograde nitric oxide signalling; slice electrophysiology

\section{Introduction}

Reproduction is sustained by the accurate physiologic performance of the hypothalamo-pituitary-gonadal (HPG) axis (Knobil, 1988; Berga and Naftolin, 2012). The different constituents of the axis form a regulatory loop and communicate with each other via hormone messengers. The descending regulatory cascade of the loop utilizes gonadotropin-releasing hormone $(\mathrm{GnRH})$ released in pulsatile manner (Belchetz et al., 1978; Clarke et al., 1987) from the hypothalamus and two gonadotrophic hormones, the luteinizing hormone (LH) and the folliclestimulating hormone $(\mathrm{FSH})$, discharged from the anterior pituitary (Knobil, 1988). The trophic effects of $\mathrm{GnRH}, \mathrm{LH}$, and FSH maintain gametogenesis and hormone production of the gonads. In females, the gonadal steroid hormones, 17 $\beta$-estradiol (E2) and progesterone, form the ascending wing of the loop that informs the brain about the actual gonadal steroid milieu at the periphery. The brain senses the progression of the gonadal cycle (Couzinet and Schaison, 1993; Berga and Naftolin, 2012) by monitoring the estrous cycle-dependent changes in blood E2 level (Nelson et al., 1992; Freeman, 1994; Christian et al., 2005; Chu et al., 2009) and shows characteristic responses to both negative (low E2) and positive (high E2) feedback effects (Caraty et al., 1995; Moenter et al., 2009; Christian and Moenter, 2010; Radovick et al., 2012). Estradiol signals reach both the $\mathrm{GnRH}$ master neurons (Hrabovszky et al., 2000, 2001, 2007; Kenealy and Terasawa, 2012) and a wide scale of neuron assemblies connected with $\mathrm{GnRH}$ cells via synapses (Gore, 2001; Moenter, 2010; Cheong et al., 2015; Adams et al., 2018). The fact that rodent $\mathrm{GnRH}$ neurons express estrogen receptors (ERs; Hrabovszky et al., 2000, 2001), particularly the $\beta$-subtype, makes the scenario of their direct targeting by the E2 feedback conceivable. Indeed, E2 can

Received February 5, 2018; accepted July 9, 2018; First published July 17, 2018

The authors declare no competing financial interests.

Author contributions: I.F., C.F., and Z.L. designed research; I.F., F.B., E.F., and C.V. performed research; I.F., F.B., E.F., and C.F. analyzed data; I.F., C.F, and Z.L. wrote the paper.

This research was supported by National Science Foundation of Hungary Grants OTKA K100722 and K115984 and by the Hungarian National Brain Research Program.

*I.F. and F.B. contributed equally to this work.

Acknowledgements: We thank Dr. M. Watanabe and Dr. E. Hrabovszky for the generous gifts of the primary antibodies. We also thank Dr. Suzanne M. Moenter for kindly providing the GnRH-GFP transgenic mice.

Correspondence should be addressed to Imre Farkas, Ph.D., Laboratory of Endocrine Neurobiology, Institute of Experimental Medicine, Hungarian Academy of Sciences, Szigony utca 43, Budapest H-1083, Hungary, E-mail: farkas.imre@koki.mta.hu.

DOI:http://dx.doi.org/10.1523/ENEURO.0057-18.2018

Copyright @ 2018 Farkas et al.

This is an open-access article distributed under the terms of the Creative Commons Attribution 4.0 International license, which permits unrestricted use, distribution and reproduction in any medium provided that the original work is properly attributed. directly influence $\mathrm{GnRH}$ neurons of female rodents (Cheong et al., 2012) suppressing various functions of these cells during the negative E2 feedback period (Kwakowsky et al., 2012; Balint et al., 2016). This negative feedback switches to positive estradiol feedback in the late afternoon of proestrus which switch is indispensable in the induction of surge release of $\mathrm{GnRH}$ eventually leading to the ovulation (Arimura et al., 1974; Moenter et al., 1990, 2009; Caraty et al., 1995; Christian and Moenter, 2010; Radovick et al., 2012). The role of the medial preoptic area (POA), the anteroventral periventricular nucleus (AVPV) and the arcuate nucleus (nARC) in mediating effects of E2 during positive feedback period and preparation of $\mathrm{GnRH}$ neurons for the surge release has been extensively studied (Ottem et al., 2004; Chakraborty et al., 2005; Smith et al., 2005, 2006; Bodo et al., 2006; Popa et al., 2008; Dungan Lemko et al., 2010; Porteous et al., 2011; Hrabovszky et al., 2012b; Liu and Herbison, 2013; Chassard et al., 2015; Dubois et al., 2015; Mittelman-Smith et al., 2016; Wang et al., 2016; Adams et al., 2018). In contrast, our current knowledge about direct targeting of mouse $\mathrm{GnRH}$ neurons by the positive E2 feedback in the proestrous phase of the ovarian cycle is limited (Farkas et al., 2013; Silveira et al., 2017). To address this issue, patch clamp electrophysiology and immunocytochemistry were used to study the putative role of ER $\beta$ and the significance of nitric oxide (NO) signaling, a recently discovered regulatory mechanism operating in $\mathrm{GnRH}$ neurons (Farkas et al., 2016; Bedenbaugh et al., 2018), in the mediation and execution of the positive E2 feedback effect directly in $\mathrm{GnRH}$ neurons.

\section{Materials and Methods}

\section{Ethics statement}

All studies were carried in accordance with legal requirements of the European Community. All animal experimentation described was conducted in accord with accepted standards of humane animal care and all efforts were made to minimize suffering.

\section{Experimental animals}

Adult, gonadally intact $\mathrm{GnRH}$-green fluorescent protein (GnRH-GFP) transgenic female mice with C57BL/6J genetic background were used for electrophysiological experiments. In this animal model, a GnRH promoter segment drives selective GFP expression in the majority of GnRH neurons (Suter et al., 2000). Phase of the estrous cycle was determined by both evaluating vaginal smears (Nelson et al., 1982; Caligioni, 2009; Byers et al., 2012) and visual observation of the vaginal opening using the method elaborated recently (Caligioni, 2009; Byers et al., 2012). In addition, mass of uterus was measured and mice having an uterus beyond $100 \mathrm{mg}$ were considered as proestrous ones, whereas animals with uterus mass below $80 \mathrm{mg}$ were regarded as metestrous ones (Silveira 
et al., 2017). Mice were maintained in $12 / 12 \mathrm{~h}$ light/dark cycle (lights on at 6 A.M.) and temperature controlled environment $\left(22 \pm 2^{\circ} \mathrm{C}\right)$, with standard rodent chow and tap water available ad libitum. All mice were housed in the same room under same environmental conditions.

\section{Brain slice preparation and recording}

Mice were deeply anesthetized by isoflurane inhalation just before termination. They were killed either in the morning between 9 and 10 A.M. and the related recordings started at 11 A.M. (experiments at the morning of proestrus) or in the afternoon between 4 and 5 P.M., and the related recordings started at 6 P.M. (experiments at the afternoon of proestrus or metestrus). After decapitation, the brain was removed rapidly and immersed in ice-cold cutting solution extensively bubbled with a mixture of $95 \% \mathrm{O}_{2}$ and $5 \% \mathrm{CO}_{2}\left(\mathrm{O}_{2} / \mathrm{CO}_{2}\right)$. The cutting solution contained the following: $205 \mathrm{mM}$ saccharose, $2.5 \mathrm{mM}$ $\mathrm{KCl}, 26 \mathrm{mM} \mathrm{NaHCO}_{3}, 5 \mathrm{mM} \mathrm{MgCl}_{2}, 1.25 \mathrm{mM} \mathrm{NaH}_{2} \mathrm{PO}_{4}, 1$ $\mathrm{mM} \mathrm{CaCl}$, and $10 \mathrm{mM}$ glucose. Forebrain blocks were dissected and $250-\mu \mathrm{m}$-thick coronal slices were prepared from the medial septum/POA with a VT-1000S Vibratome (Leica $\mathrm{GmbH}$ ) and placed in the ice-cold oxygenated cutting solution. The slices containing POA were transferred into artificial CSF (aCSF; $130 \mathrm{mM} \mathrm{NaCl}, 3.5 \mathrm{mM}$ $\mathrm{KCl}, 1.25 \mathrm{mM} \mathrm{NaH}_{2} \mathrm{PO}_{4}, 1.2 \mathrm{mM} \mathrm{MgSO}_{4}$, $2.5 \mathrm{mM} \mathrm{CaCl}_{2}$, $26 \mathrm{mM} \mathrm{NaHCO}$, and $10 \mathrm{mM}$ glucose) saturated with $\mathrm{O}_{2} / \mathrm{CO}_{2}$ and kept in it for $1 \mathrm{~h}$ to equilibrate. Equilibration started at $33^{\circ} \mathrm{C}$, and the aCSF was allowed to cool to room temperature. Mass of uterus was measured after brain cutting and slices from metestrous mice having uterus beyond $80 \mathrm{mg}$, and those from proestrous mice below $100 \mathrm{mg}$ were discarded (Silveira et al., 2017).

Electrophysiological recordings were conducted at $33^{\circ} \mathrm{C}$ in aCSF bubbled with $\mathrm{O}_{2} / \mathrm{CO}_{2}$. Axopatch $200 \mathrm{~B}$ patch clamp amplifier, Digidata-1322A data acquisition system, and PCLAMP 10.4 software (Molecular Devices Co.) were used for recording. Cells were visualized with a BX51WI IR-DIC microscope (Olympus Co.) located on an anti-vibration table (Supertech $\mathrm{Kft}$ ). The patch electrodes $(\mathrm{OD}=1.5 \mathrm{~mm}$, thin wall; Hilgenberg $\mathrm{GmbH})$ were pulled with a Flaming-Brown P-97 puller (Sutter Instrument Co., Novato, CA) and polished with an MF-830 microforge (Narishige). GnRH-GFP neurons were identified by brief illumination at $470 \mathrm{~nm}$ using an epifluorescent filter set, based on their green fluorescence, typical fusiform shape, and topographic location in the POA (Suter et al., 2000).

\section{Whole-cell patch clamp experiments}

The cells were voltage clamped at $-70-\mathrm{mV}$ holding potential. Pipette offset potential, series resistance $\left(R_{s}\right)$ and capacitance were compensated before recording. Only cells with low holding current $(<\approx 10 \mathrm{pA})$ and stable baseline were used. Input resistance $\left(R_{i n}\right), R_{s}$, and membrane capacitance $\left(\mathrm{C}_{\mathrm{m}}\right)$ were also measured before each recording by using $5-\mathrm{mV}$ hyperpolarizing pulses. To ensure consistent recording qualities, only cells with $R_{s}<20 \mathrm{M} \Omega$, $R_{\text {in }}>500 \mathrm{M} \Omega$, and $C_{m}>10 \mathrm{pF}$ were accepted.

There is a widely accepted consensus that GABA is excitatory via $G A B A_{A}-R$ in $G n R H$ neurons due to the high intracellular chloride concentration in these cells (DeFazio et al., 2002; Moenter and DeFazio, 2005; Herbison and Moenter, 2011). Our main goal was to mimic the physiologic conditions of $\mathrm{GnRH}$ neurons as much as possible during the entire experiment, therefore, high concentration of chloride in the intracellular solution was indispensable. According to this requirement, the intracellular pipette solution contained high amount of chloride: 10 mM HEPES, $140 \mathrm{mM} \mathrm{KCl,} 5 \mathrm{mM}$ EGTA, $0.1 \mathrm{mM} \mathrm{CaCl}_{2}, 4$ $\mathrm{mM} \mathrm{Mg}-\mathrm{ATP}$, and $0.4 \mathrm{mM}$ Na-GTP (pH 7.3). The resistance of the patch electrodes was 2-3 M . For the miniature PSC (mPSC) measurements, 10 min before the start of recording, the spike-mediated transmitter release was blocked by adding the voltage sensitive $\mathrm{Na}$-channel inhibitor tetrodotoxin (TTX; $646 \mathrm{nM}$; Tocris) to the aCSF. In the experiments, where the involved neurotransmitter receptors were examined, the $\mathrm{GABA}_{\mathrm{A}}-\mathrm{Rs}$ were blocked by picrotoxin $(100 \mu \mathrm{M})$, the ionotropic glutamate-receptors (Glu-Rs) were inhibited by the Glu-R inhibitor kynurenic acid (2 mM), and the AMPA/kainate-Rs were antagonised by the AMPA kainate-R antagonist NBQX $(10 \mu \mathrm{M})$, added to the aCSF during the respective recordings. To demonstrate the effect of E2, the recordings were conducted with an initial control recording ( $5 \mathrm{~min}$ ), then high physiologic dose of E2 (200 pM, Sigma), characteristic for the proestrous phase of the estrous cycle in rodents (Nelson et al., 1992; Christian et al., 2005; Freeman, 2006; Chu et al., 2009), was added to the aCSF in the recording chamber and the recording continued for a subsequent $10 \mathrm{~min}$. Stock of E2 (10 mM) was prepared in DMSO, which was diluted in aCSF to reach the final working concentration (200 pM) pipetted onto the slice in a single bolus. Instantaneous volume of the aCSF in the chamber was $1.5 \mathrm{ml}$. A single bolus of $3 \mu \mathrm{l}$ of $100 \mathrm{nM}$ E2 (diluted in aCSF) was pipetted to the inlet of the chamber. Using these volume and concentration data, $3 \mu \mathrm{l}$ of $100 \mathrm{nM}$ E2 in $1.5 \mathrm{ml}$ aCSF gives the actual dose of E2 (200 pM) in the chamber. Flow rate of perfusion was $3 \mathrm{ml} / \mathrm{min}$. When the ER $\beta$ antagonist 4-[2phenyl-5,7-bis(trifluoromethyl)pyrazolo[1,5-a]pyrimidin-3yl]phenol (PHTPP; $1 \mu \mathrm{M})$ was used extracellularly, it was added to the aCSF 10 min before starting the recording, whereas in case of its intracellular application (intraPHTPP) the drug was added to the intracellular solution in the pipette. The membrane-impermeable NO-scavenger 2-(4carboxyphenyl)-4,4,5,5-tetramethylimidazoline-1-oxyl-3oxide (CPTIO; $1 \mathrm{mM}$ ), the Src kinase inhibitor 4-amino-3-(4chlorophenyl)-1-(t-butyl)-1H-pyrazolo[3,4-d]pyrimidine,4amino-5-(4-chlorophenyl)-7-(t-butyl)pyrazolo[3,4]pyrimidine (PP2; $10 \mu \mathrm{M}$ ) or the phosphatidylinositol 3 kinase (PI3K) blocker 2-(4-morpholinyl)-8-phenyl-1(4H)benzopyran-4-one hydrochloride (LY294002; $50 \mu \mathrm{M})$ were added to the intracellular solution in the pipette to block NO production and release in the measured $\mathrm{GnRH}$ neuron. The pipette solution containing intracellularly applied drug was allowed to equilibrate with the intracellular milieu of the cell for $15 \mathrm{~min}$ before starting recording.

Time distribution graphs of frequencies were generated by using 1-min time bins to show time courses of effect of E2.

To show action of E2 onto the firing, resting potential $\left(V_{\text {rest }}\right), R_{\text {in }}$, and $C_{m}$ in $\mathrm{GnRH}$ neurons of proestrous mice, 
Table 1. Statistical table

\begin{tabular}{|c|c|c|c|}
\hline & Data structure & Type of test & Power \\
\hline a & Normal distribution & Student's $t$ test & 0.95 \\
\hline b & Normal distribution & $\begin{array}{l}\text { One-way ANOVA with } \\
\text { Dunnet's post } \\
\text { hoc test }\end{array}$ & 0.95 \\
\hline c & Normal distribution & One-way ANOVA & 0.95 \\
\hline d & Normal distribution & Kolmogorov-Smirnov & 0.95 \\
\hline
\end{tabular}

current clamp measurements were conducted. Three 900-ms-long current steps were applied $(-25,0$, and +25 $\mathrm{pA}) . \mathrm{V}_{\text {rest }}$ was evaluated from the $0-\mathrm{pA}$ step, firing was analyzed during the depolarizing step. The $\mathrm{R}_{\text {in }}$ was determined from the voltage response to the application of hyperpolarizing current. The time constant was the time required to reach $63 \%$ of the maximum voltage response to hyperpolarizing current (Spergel et al., 1999). The $C_{m}$ was then calculated by dividing the time constant by the $\mathrm{R}_{\mathrm{in}}$. After control recording, E2 was pipetted into the measurement chamber and 1, 3, 5, and 10 min later, the three current steps were repeated.

\section{Loose patch measurements}

Recording of action current firing of $\mathrm{GnRH}$ neurons was conducted at $33^{\circ} \mathrm{C}$. Pipette potential was $0 \mathrm{mV}$, pipette resistance 1-2 $M \Omega$, and resistance of loose-patch seal 7-40 M $\Omega$. The pipette solution contained: $150 \mathrm{mM} \mathrm{NaCl}$, $3.5 \mathrm{mM} \mathrm{KCl}, 2.5 \mathrm{mM} \mathrm{CaCl}_{2}, 1.3 \mathrm{mM} \mathrm{MgCl}_{2}, 10 \mathrm{mM}$ HEPES, and $10 \mathrm{mM}$ glucose (pH 7.3).

After recording basal action currents, the E2 (200 pM) was added in a single bolus to the brain slice in the recording chamber, and the recording continued for a subsequent $10 \mathrm{~min}$, similarly to the method described in the whole-cell clamp measurements.

\section{Reagents and chemicals}

$\mathrm{GABA}_{A}-\mathrm{R}$ blocker picrotoxin (100 $\mu \mathrm{M}$, Sigma; Seidl et al., 2014; Keshavarzi et al., 2015); the wide-spectrum ionotropic Glu-R inhibitor kynurenic acid (2 mM, Sigma; Zheng et al., 2011; Ide et al., 2013); the AMPA/kainate receptor (AMPA/kainate-R) antagonist 2,3-dihydroxy-6nitro-7-sulfamoyl-benzo[f]quinoxaline-2,3-dione (NBQX, $10 \mu \mathrm{M}$; Tocris; Keshavarzi et al., 2015; Lo et al., 2016); the ER $\beta$ antagonist PHTPP ( $1 \mu \mathrm{M}$; Tocris; Kajta et al., 2013; Saleh et al., 2013); the membrane-impermeable NOscavenger CPTIO (1 mM, Sigma; Makara et al., 2007; Mironov and Langohr, 2007); E2 (200 pM, Sigma; Nelson et al., 1992; Christian et al., 2005; Freeman, 2006; Chu et al., 2009); the Src kinase inhibitor PP2 (10 $\mu \mathrm{M}$; Sigma; Grishin et al., 2005); the PI3K inhibitor LY294002 (50 $\mu \mathrm{M}$; Sigma; Zhang et al., 2016).

\section{Statistical analysis}

For electrophysiology, each experimental group contained 8-12 recorded cells from six to nine animals. Recordings were stored and analyzed off-line. The mPSC frequency was calculated as number of spikes divided by the length of the respective period ( 5 min "control period" and 10 min "agonist period," respectively). The effect of the treatments was displayed as a percentage ratio of the value of the respective mPSC parameter of the control and the agonist period. Each neuron served as its own control when drug effects were evaluated. Event detection was performed using the Clampfit module of the PClamp 10.4 software (Molecular Devices Co.). Group data were expressed as mean \pm SEM. Statistical analyses were conducted using Prism 3.0 (GraphPad Software, Inc.) and Statistica 13.1 (Dell Software). Two-tailed Student's $t$ test, and one-way ANOVA test followed by Dunnett's (ANOVA+D) post hoc test were applied for comparison of groups and the differences were considered as significant at $p<0.05$. Cumulative probabilities of interevent intervals of each group were pooled (Liu et al., 2017) and analyzed by using Kolmogorov-Smirnov test to show statistical differences between the frequencies of the control and E2-treated neurons (Table 1).

\section{Animal preparation for triple-labeling immunocytochemistry}

Mice $(n=4)$ were anaesthesized with a mixture of ketamine and xylazine (ketamine $50 \mathrm{mg} / \mathrm{kg}$, xylazine 10 $\mathrm{mg} / \mathrm{kg}$ body weight, i.p.) at 4:30 P.M. on the day of proestrus and were perfused transcardially with $10 \mathrm{ml}$ $0.01 \mathrm{M}$ PBS $\mathrm{pH} 7.4$, followed by $50 \mathrm{ml} 4 \%$ paraformaldehyde in $0.1 \mathrm{M}$ phosphate buffer $\mathrm{pH} 7.4$ (PB). The brains were rapidly removed and the brains were cryoprotected in $30 \%$ sucrose in $0.01 \mathrm{M}$ PBS overnight at room temperature.

\section{Tissue preparation for triple-labeling immunofluorescence}

Serial, $25-\mu \mathrm{m}$-thick coronal sections through the vascular organ of the lamina terminalis (VOLT) were cut on freezing microtome. The sections were pretreated first with $0.5 \%$ Triton $X-100$ and $0.5 \% \mathrm{H}_{2} \mathrm{O}_{2}$ in $0.01 \mathrm{M}$ PBS for 15 min. Nonspecific antibody binding was blocked with treatment in $2 \%$ normal horse serum (NHS) in PBS for 20 $\min$.

\section{Triple-labeling immunofluorescence for $\mathrm{GnRH}$, sGC, and vGLUT2 or vGAT}

Sections were incubated in a primary antibody mix containing guinea-pig anti-GnRH serum at 1:5000 dilution (gift from E. Hrabovszky), rabbit anti-soluble guanylate cyclase $\alpha 1$ subunit (sGC) serum at 1:250 dilution (Sigma) and either sheep anti-vesicular glutamate transporter 2 (vGLUT2) serum at 1:1000 dilution (gift from M. Watanabe) or mouse anti-vGLUT2 serum at 1:1000 dilution (Millipore Bioscience Research Reagents) or sheep anti-vesicular GABA transporter (vGAT) serum at 1:5000 dilution (gift from M. Watanabe) in $2 \% \mathrm{NHS}$ for $2 \mathrm{~d}$ at $4^{\circ} \mathrm{C}$. Then, the sections were incubated in a mixture of Alexa Fluor 488conjugated donkey anti guinea-pig IgG (1:250, Jackson), Dylight 405-conjugated donkey anti-sheep or mouse IgG (1:250, Jackson), and Alexa Fluor 555-conjugated donkey anti-rabbit IgG (1:500, Jackson) for $2 \mathrm{~h}$, mounted onto glass slides, and cover slipped with Vectashield mounting medium (Vector).

Representative images were taken using Zeiss LSM 780 confocal microscope (Carl Zeiss $\mathrm{GmbH}$ ) using line by line sequential scanning with laser excitation lines 410- 
a

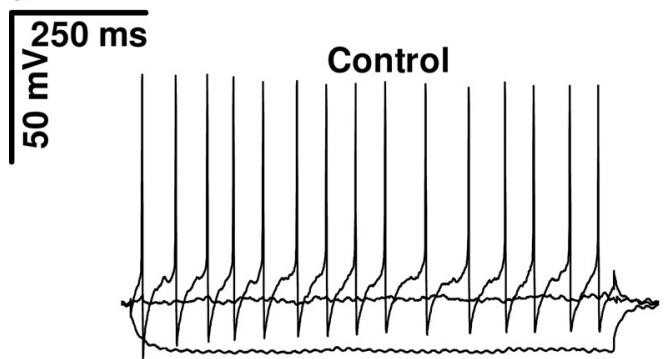

b

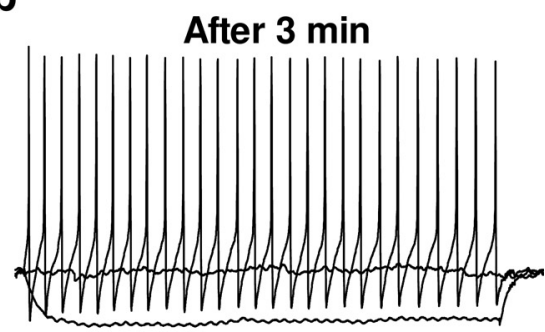

Current stimuli

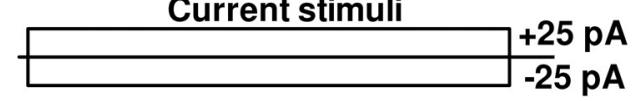

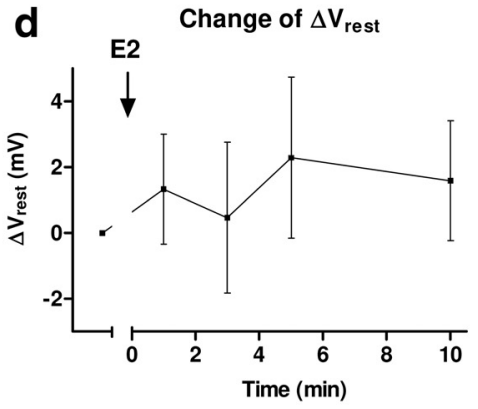

f Percentage change of capacitance

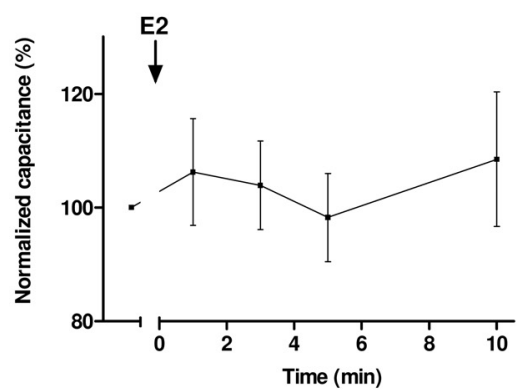

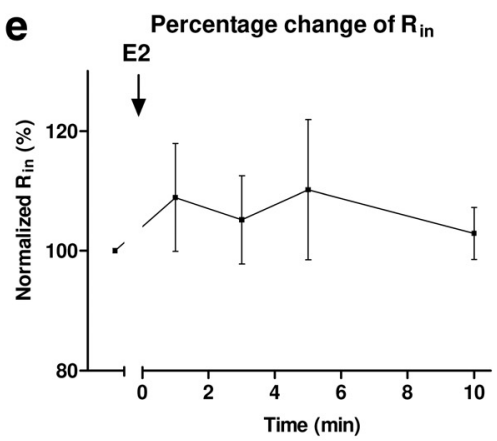

Proestrus pm loose patch

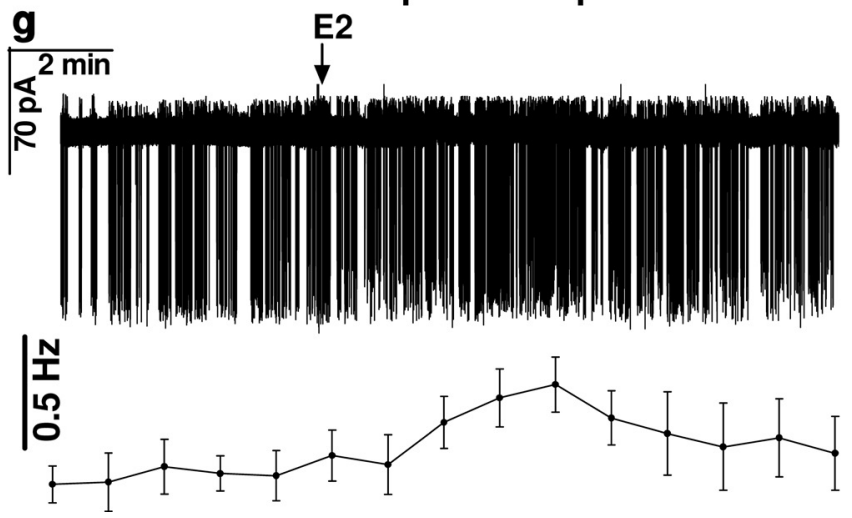

Figure 1. High physiologic concentration of E2 (200 pM) increases firing in GnRH neurons. $\boldsymbol{A}-\boldsymbol{C}$, Number of APs elevated 3 min after E2 administration evoked by the depolarizing current step. $\boldsymbol{D}$, Changes in the resting potential showed no significant alteration. $\boldsymbol{E}$, $\mathrm{R}_{\text {in }}$ presented no E2-dependent change during the 10 min period examined. $\boldsymbol{F}$, Membrane capacitance also showed no change. $\mathbf{G}$, Loose patch clamp recording also confirmed the elevation of firing rate; $* p<0.05$. 
Table 2. Changes in firing, $V_{\text {rest }}, R_{i n}$, and $C_{m}$ in $\mathrm{GnRH}$ neurons on $E 2$ administration

\begin{tabular}{|c|c|c|c|c|c|c|c|}
\hline & Control value & Change (1 min) & Change (3 min) & Change (5 min) & Change (10 min) & $N / n$ & df \\
\hline Number of APs & $19.5 \pm 2.45$ & $\begin{array}{l}109.3 \pm 7.4 \\
\%\end{array}$ & $\begin{array}{l}121.1 \pm 8.3 \\
\%\end{array}$ & $\begin{array}{l}115.7 \pm 10.1 \\
\%\end{array}$ & $\begin{array}{l}110.5 \pm 10.1 \\
\%\end{array}$ & $7 / 4$ & 6 \\
\hline$t$ & & 1.257 & 2.548 & 1.559 & 1.035 & & \\
\hline$p^{a}$ & & 0.2556 & 0.0436 & 0.1700 & 0.3405 & & \\
\hline $\mathrm{V}_{\text {rest }}$ & $\begin{array}{l}-53.6 \pm 3.8 \\
m V\end{array}$ & $\begin{array}{l}1.33 \pm 1.67 \\
\mathrm{mV}\end{array}$ & $\begin{array}{l}0.46 \pm 2.28 \\
\mathrm{mV}\end{array}$ & $\begin{array}{l}2.29 \pm 2.45 \\
\mathrm{mV}\end{array}$ & $\begin{array}{l}1.59 \pm 1.82 \\
m V\end{array}$ & $7 / 4$ & 6 \\
\hline$t$ & & 0.7971 & 0.2037 & 0.9368 & 0.8751 & & \\
\hline$p^{a}$ & & 0.4558 & 0.8453 & 0.3850 & 0.4152 & & \\
\hline $\mathrm{R}_{\mathrm{in}}$ & $\begin{array}{l}998.4 \pm 127.8 \\
\text { MOhm }\end{array}$ & $\begin{array}{l}108.9 \pm 9.0 \\
\%\end{array}$ & $\begin{array}{l}105.2 \pm 7.3 \\
\%\end{array}$ & $\begin{array}{l}110.2 \pm 11.7 \\
\%\end{array}$ & $\begin{array}{l}102.9 \pm 4.4 \\
\%\end{array}$ & $7 / 4$ & 6 \\
\hline$t$ & & 0.9903 & 0.7067 & 0.8739 & 0.6694 & & \\
\hline$p^{\mathrm{a}}$ & & 0.3603 & 0.5063 & 0.4158 & 0.5281 & & \\
\hline Capacitance & $\begin{array}{l}26.37 \pm 1.1 \\
\mathrm{pF}\end{array}$ & $\begin{array}{l}106.2 \pm 9.4 \\
\%\end{array}$ & $\begin{array}{l}103.9 \pm 7.8 \\
\%\end{array}$ & $\begin{array}{l}98.2 \pm 7.7 \\
\%\end{array}$ & $\begin{array}{l}108.5 \pm 11.8 \\
\%\end{array}$ & $7 / 4$ & 6 \\
\hline$t$ & & 0.6632 & 0.4986 & 0.2269 & 0.7194 & & \\
\hline$p^{a}$ & & 0.5318 & 0.6358 & 0.8280 & 0.4990 & & \\
\hline
\end{tabular}

$N=$ number of neurons measured. $n=$ number of animals used for the given experiment.

$\mathrm{df}=$ degree of freedom of Student's $t$ test of percentage data where each neuron serves as its own control.

$t=t$ values of Student's $t$ test of percentage data.

$p=p$ probability values of Student's $t$ test of percentage data.

$\mathrm{C}_{\mathrm{m}}=$ cell capacitance.

$483 \mathrm{~nm}$ for Dylight 405, 490-553 nm for Alexa Fluor 488, and 566-697 nm for Alexa Fluor 555; beam splitter/ emission filters, main beam splitter (MSB) $405 \mathrm{~nm}$ for Alexa Fluor 405, MSB488/561 nm for Alexa Fluor 488, and Alexa Fluor 555. For $40 \times$ and $60 \times$ oil lenses, pinhole sizes were set to obtain optical slices of 2 and $<1 \mu \mathrm{m}$ in thickness, respectively, and the series of optical sections were recorded with 0.6- $\mu \mathrm{m} \mathrm{Z} \mathrm{steps.}$

Images were analyzed with Zen 2012 (Carl Zeiss GmbH) and with Adobe Photoshop (Adobe System Inc.).

For the quantitative analyses, the images were taken using C2 Nikon confocal microscope (Nikon) using laser excitation lines $408 \mathrm{~nm}$ for Dylight 405, $488 \mathrm{~nm}$ for Alexa Fluor 488, and $561 \mathrm{~nm}$ for Alexa Fluor 555, dichroic mirror: 405(408)/457(440)/561/640(633); emission filters: 510/84 bandpass filter for Dylight 405, 593/40 bandpass filter for Alexa Fluor 488, and 635 long pass filter. Z-stack series of images were taken using a $60 \times$ oil immersion lens and the pinhole size was set to optimal for the lens. The series of the optical sections were recorded with $0.5-\mu \mathrm{m} \mathrm{Z}$ steps and the analyzed cells thickness were minimum $6 \mu \mathrm{m}$ ( $>10$ images). For the analyses we used orthogonal view in the NIS-elements Viewer 4.20 program and the colocalisation was accepted if it was seen in $X Y, X Z$, and $Y Z$ planes. Juxtaposition was accepted if there was no visible gap between the GnRH-IR neuron and and the axon varicosity. Seven to nine sections were scanned from each animal (vGLUT2 $n=3$; vGAT $n=4$ ). A total of 1051 vGAT-IR varicosities were counted on the surface of 97 GnRH neurons, and 938 vGLUT2-IR varicosities were counted on the surface of $68 \mathrm{GnRH}$ neurons.

The specificity of GnRH (Hrabovszky et al., 2011), sGC $\alpha 1$ (Szabadits et al., 2007), vGAT (Hrabovszky et al., 2012a), and vGLUT2 (Hrabovszky et al., 2012a) antibodies has been reported in the literature (for statistics, see Table 1).

\section{Results}

\section{High physiologic concentration of E2 increases firing} rate in GnRH neurons in proestrus afternoon

Plasma concentration of E2 in proestrus afternoon (proestrus P.M.) is in the range of a couple of hundred pM in rodents (Nelson et al., 1992; Freeman, 1994). In humans, the preovulatory level of E2 is also several hundred pM (Lin and Sun, 2005). Therefore, we administered E2 at $200 \mathrm{pM}$ in our electrophysiological experiments, modeling the high physiologic dose characteristic for the proestrous afternoon stage of the gonadal cycle. Current clamp measurements revealed that 3 min after the $\mathrm{E} 2$ application the number of action potentials (APs) evoked by the depolarizing current injection increased significantly (121.14 \pm $8.30 \%$ of the control value $19 \pm 2.4$ APs, $p=0.041^{\text {a }}$; Fig. $1 A-C$; Table 2). Other parameters, such as $\Delta \mathrm{V}_{\text {rest }}, \mathrm{R}_{\mathrm{in}}$, and $\mathrm{C}_{\mathrm{m}}$ showed no change (Fig. 1D-F; Table 2). Loose patch recordings demonstrated similar increase in the firing rate (134 $\pm 12.1 \%$ of the control value $0.59 \pm 0.08 \mathrm{~Hz}$, seven neurons from four mice, Student's $t$ test, $\mathrm{df}=6, t=2.746$, $p=0.0335^{\text {a }}$; Fig. 1G).

\section{E2 increases frequency of mPSCs in GnRH neurons in proestrus afternoon}

Application of E2 (200 pM) resulted in a significant increase in the frequency of mPSCs $(153.2 \pm 17.33 \%$ of the control value $1.869 \pm 0.1877 \mathrm{~Hz}$ ) in $\mathrm{GnRH}$ neurons (Student's $t$ test, $p=0.0107^{\text {a; }}$ Fig. $2 A$; Table 3). Elevation of the mPSC frequency started in 1-2 min after administration of E2 and slowly dampened after $\sim 10$-min-long period of washout, as shown by the frequency distribution graph under the recording. Cumulative probability plots also demonstrated significant differences between the control and the treated interevent intervals (KolmogorovSmirnov, $p=0.0081^{\mathrm{d}}$ ). In contrast, values of amplitude, rise, and decay $\tau$ of the mPSCs presented no significant change (Table 3 ). These results together suggested the 
a
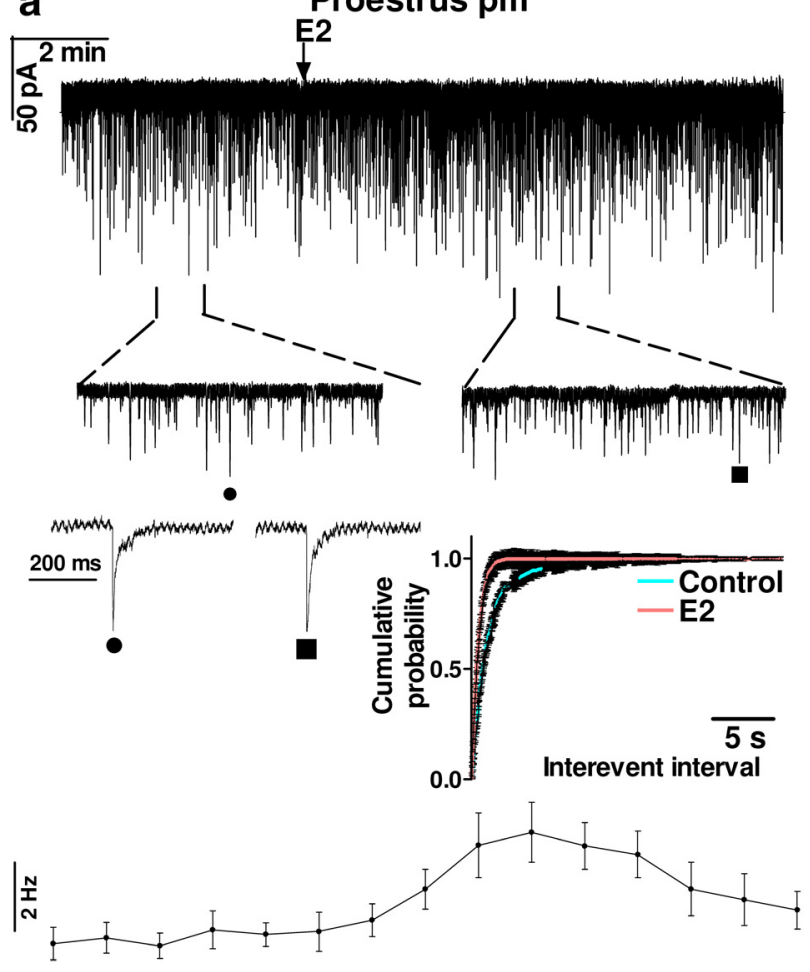

C

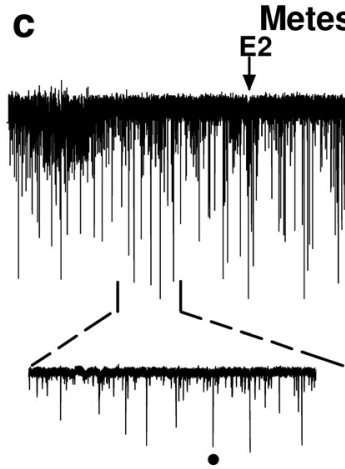

Metestrus pm
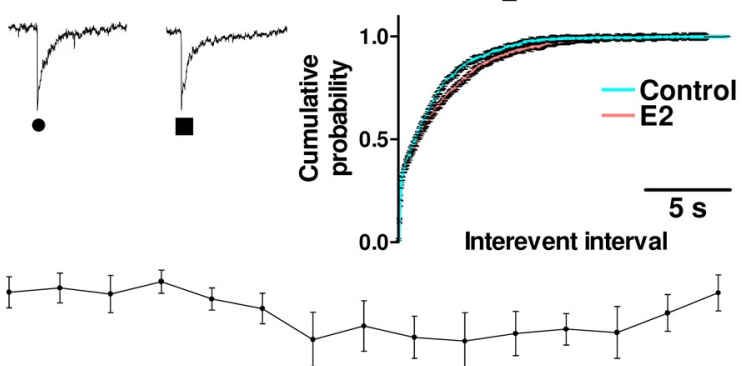

b

Proestrus am
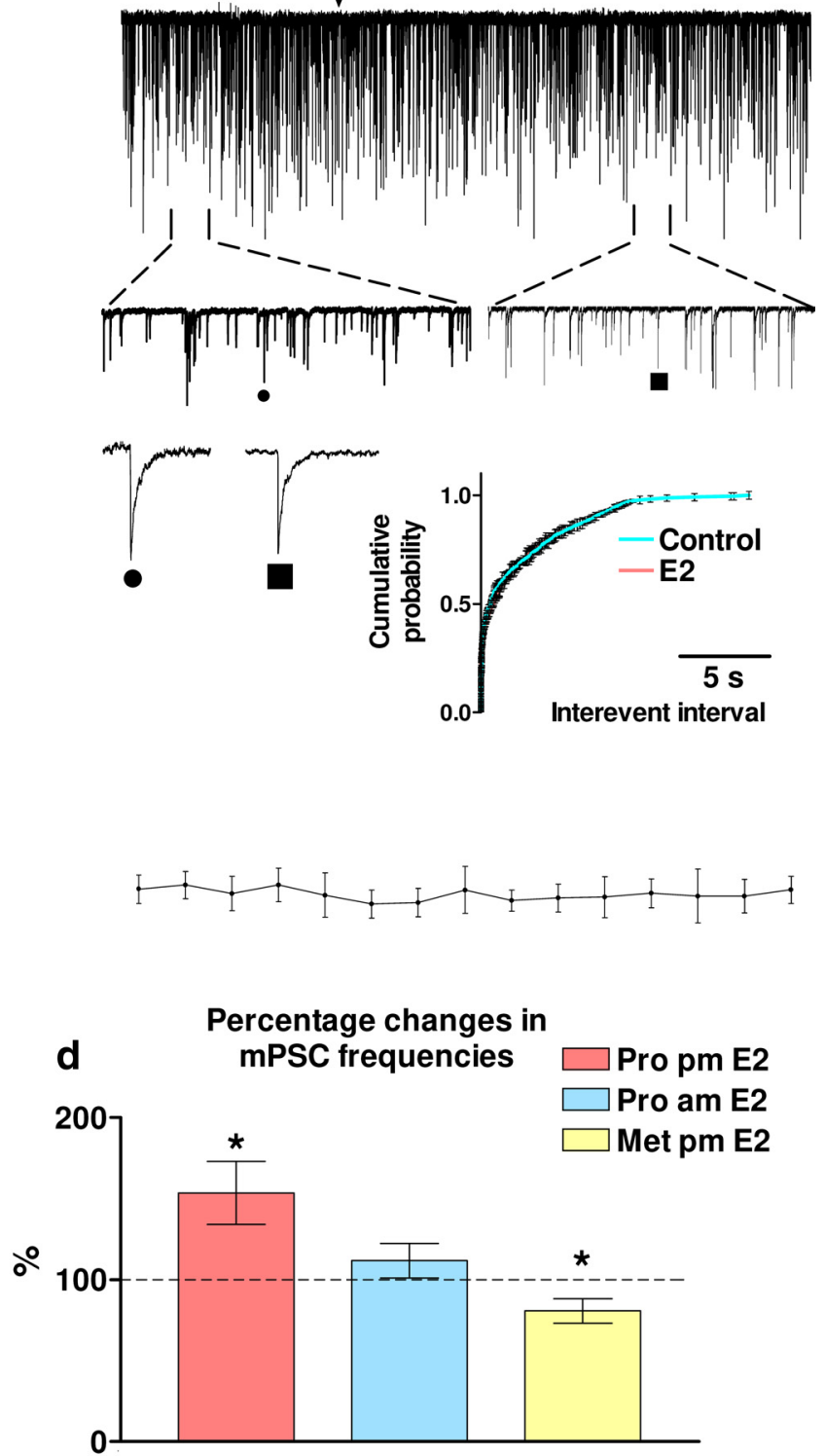

Figure 2. Effect of high physiologic concentration of E2 (200 pM) on the mPSCs of GnRH neurons in various phases of the estrous cycle. $\boldsymbol{A}$, E2 increased frequency of mPSCs in proestrus afternoon. $\boldsymbol{B}, \mathrm{mPSC}$ frequency showed no change when E2 was administered in proestrus morning. $\boldsymbol{C}$, E2 decreased mPSC frequency in metestrus afternoon. $\boldsymbol{D}$, Bar graph exhibits that E2 facilitated fast inputs to $\mathrm{GnRH}$ neurons in proestrus afternoon significantly but not in proestrus morning or in metestrus afternoon. The inserts below the 15 min recordings are 1-1 min zoomed periods from the respective recording before and after E2 administration. Individual PSC events are also shown from the control (to indentify in the 1-min zoomed periods, it is tagged by $\bullet$ ) and the E2-treated (tagged by -) periods. Time course of the mean frequency and cumulative probabilities of the interevent intervals are presented under each recording; $* p<0.05$. 
Table 3. Changes in mPSC parameters in GnRH neurons on E2 administration

\begin{tabular}{|c|c|c|c|c|c|c|}
\hline Frequency of mPSCs & Frequency of control period $(\mathrm{Hz})$ & Percentage change (\%) & $N / n$ & df & $t$ & $p$ \\
\hline Pro pm E2 & $1.869 \pm 0.1877$ & $153.2 \pm 17.33$ & $12 / 7$ & 11 & 3.067 & $0.0107^{a}$ \\
\hline Pro am E2 & $1.074 \pm 0.2078$ & $110.2 \pm 8.58$ & $12 / 8$ & 11 & 1.189 & $0.2593^{a}$ \\
\hline Met pm E2 & $1.120 \pm 0.2290$ & $80.6 \pm 7.54$ & $9 / 6$ & 8 & 2.591 & $0.0321^{a}$ \\
\hline Pro pm PHTPP+E2 & $2.059 \pm 0.2281$ & $93.4 \pm 9.07$ & $7 / 4$ & 6 & 0.7243 & $0.4962^{a}$ \\
\hline Pro pm intraPHTPP +E2 & $1.790 \pm 0.5129$ & $97.1 \pm 9.16$ & $7 / 5$ & 6 & 0.3222 & $0.7582^{a}$ \\
\hline Pro pm CPTIO+E2 & $2.006 \pm 0.2569$ & $106.1 \pm 5.93$ & $9 / 5$ & 8 & 1.027 & $0.3346^{a}$ \\
\hline Pro pm PP2+E2 & $1.555 \pm 0.2891$ & $106.2 \pm 6.06$ & $8 / 6$ & 7 & 1.014 & $0.3441^{a}$ \\
\hline Pro pm LY294002+E2 & $1.703 \pm 0.1989$ & $102.2 \pm 5.88$ & $8 / 6$ & 7 & 0.3805 & $0.7148^{a}$ \\
\hline Pro pm Kynu+E2 & $1.279 \pm 0.2357$ & $133.7 \pm 12.27$ & $7 / 4$ & 6 & 2.746 & $0.0335^{a}$ \\
\hline Pro pm Picro+E2 & $0.631 \pm 0.1376$ & $143.1 \pm 17.23$ & $7 / 4$ & 6 & 2.492 & $0.0470^{\mathrm{a}}$ \\
\hline Amplitude of mPSCs & Amplitude of control period $(\mathrm{pA})$ & Percentage change (\%) & $N$ & df & $t$ & $p$ \\
\hline Pro pm E2 & $-24.43 \pm 2.067$ & $100.7 \pm 2.19$ & $12 / 7$ & 11 & 0.2760 & $0.7952^{a}$ \\
\hline Pro am E2 & $-36.41 \pm 5.148$ & $101.5 \pm 1.15$ & $12 / 8$ & 11 & 1.343 & $0.2062^{a}$ \\
\hline Met pm E2 & $-34.51 \pm 6.257$ & $101.2 \pm 2.84$ & $9 / 6$ & 8 & 0.4301 & $0.6785^{a}$ \\
\hline Pro pm PHTPP+E2 & $-26.48 \pm 3.562$ & $97.0 \pm 2.19$ & $7 / 4$ & 6 & 1.368 & $0.2203^{a}$ \\
\hline Pro pm intraPHTPP+E2 & $-27.72 \pm 8.614$ & $99.1 \pm 1.18$ & $7 / 5$ & 6 & 0.7337 & $0.4908^{a}$ \\
\hline Pro pm CPTIO+E2 & $-25.05 \pm 2.062$ & $102.7 \pm 2.192$ & $9 / 5$ & 8 & 1.216 & $0.2585^{\mathrm{a}}$ \\
\hline Pro pm PP2+E2 & $-26.46 \pm 2.464$ & $101.8 \pm 3.84$ & $8 / 6$ & 7 & 0.4638 & $0.6569^{a}$ \\
\hline Pro pm LY294002+E2 & $-36.90 \pm 4.897$ & $100.7 \pm 1.18$ & $8 / 6$ & 7 & 0.5812 & $0.5793^{a}$ \\
\hline Pro pm Kynu+E2 & $-36.83 \pm 2.286$ & $98.1 \pm 2.37$ & $7 / 4$ & 6 & 0.7722 & $0.4693^{a}$ \\
\hline Pro pm Picro+E2 & $-19.64 \pm 2.107$ & $97.0 \pm 2.58$ & $7 / 4$ & 6 & 1.162 & $0.2894^{a}$ \\
\hline Rise $\tau$ of mPSCs & Rise $\tau$ of control period (ms) & Percentage change (\%) & $N$ & df & $t$ & $p$ \\
\hline Pro pm E2 & $3.941 \pm 0.5402$ & $138.8 \pm 43.13$ & $12 / 7$ & 11 & 0.8985 & $0.3882^{\mathrm{a}}$ \\
\hline Pro am E2 & $4.287 \pm 0.1746$ & $134.3 \pm 20.29$ & $12 / 8$ & 11 & 1.688 & $0.1194^{a}$ \\
\hline Met pm E2 & $4.760 \pm 0.6285$ & $109.1 \pm 16.41$ & $9 / 6$ & 8 & 0.5552 & $0.5939^{a}$ \\
\hline Pro pm PHTPP+E2 & $3.710 \pm 0.2690$ & $103.3 \pm 14.27$ & $7 / 4$ & 6 & 0.2302 & $0.8256^{a}$ \\
\hline Pro pm intraPHTPP+E2 & $4.175 \pm 0.9160$ & $116.7 \pm 24.64$ & $7 / 5$ & 6 & 0.6763 & $0.5241^{a}$ \\
\hline Pro pm CPTIO+E2 & $3.771 \pm 0.4979$ & $143.9 \pm 44.24$ & $9 / 5$ & 8 & 1.611 & $0.1459^{a}$ \\
\hline Pro pm PP2+E2 & $3.970 \pm 0.4466$ & $99.1 \pm 13.22$ & $8 / 6$ & 7 & 0.0657 & $0.9494^{a}$ \\
\hline Pro pm LY294002+E2 & $3.708 \pm 0.2870$ & $92.6 \pm 9.09$ & $8 / 6$ & 7 & 0.818 & $0.4403^{a}$ \\
\hline Pro pm Kynu+E2 & $4.220 \pm 0.4710$ & $101.2 \pm 14.99$ & $7 / 4$ & 6 & 0.0789 & $0.9396^{a}$ \\
\hline Pro pm Picro+E2 & $3.006 \pm 0.1134$ & $124.4 \pm 27.99$ & $7 / 4$ & 6 & 0.8729 & $0.4163^{a}$ \\
\hline Decay $\tau$ of $\mathrm{mPSCs}$ & Decay $\tau$ of control period (ms) & Percentage change (\%) & $N$ & df & $t$ & $p$ \\
\hline Pro pm E2 & $10.60 \pm 2.416$ & $137.2 \pm 27.44$ & $12 / 7$ & 11 & 1.656 & $0.1259^{a}$ \\
\hline Pro am E2 & $13.04 \pm 5.393$ & $130.8 \pm 24.20$ & $12 / 8$ & 11 & 1.272 & $0.2297^{a}$ \\
\hline Met pm E2 & $13.34 \pm 1.805$ & $141.4 \pm 23.43$ & $9 / 6$ & 8 & 1.768 & $0.1150^{a}$ \\
\hline Pro pm PHTPP+E2 & $13.44 \pm 3.977$ & $105.3 \pm 22.41$ & $7 / 4$ & 6 & 0.2359 & $0.8214^{a}$ \\
\hline Pro pm intraPHTPP+E2 & $11.83 \pm 1.433$ & $125.7 \pm 16.45$ & $7 / 5$ & 6 & 1.562 & $0.1692^{a}$ \\
\hline Pro pm CPTIO+E2 & $13.62 \pm 2.368$ & $113.4 \pm 22.79$ & $9 / 5$ & 8 & 0.5898 & $0.5716^{a}$ \\
\hline Pro pm PP2+E2 & $10.67 \pm 1.033$ & $94.5 \pm 7.38$ & $8 / 6$ & 7 & 0.7455 & $0.4803^{a}$ \\
\hline Pro pm LY294002+E2 & $13.45 \pm 2.559$ & $97.3 \pm 9.51$ & $8 / 6$ & 7 & 0.2853 & $0.7837^{a}$ \\
\hline Pro pm Kynu+E2 & $12.48 \pm 1.152$ & $103.5 \pm 8.27$ & $7 / 4$ & 6 & 0.4269 & $0.6843^{a}$ \\
\hline Pro pm Picro+E2 & $5.62 \pm 1.101$ & $79.3 \pm 21.57$ & $7 / 4$ & 6 & 0.9602 & $0.3740^{a}$ \\
\hline
\end{tabular}

$N=$ number of neurons measured. $n=$ number of animals used for the given experiment.

$\mathrm{df}=$ degree of freedom of Student's $t$ test of percentage data where each neuron serves as its own control.

$t=t$ values of Student's $t$ test of percentage data.

$p=p$ probability values of Student's $t$ test of percentage data.

Pro = proestrus; Met = metestrus; am = morning; pm = afternoon

involvement of a presynaptic process in the effect of E2 on the recorded mPSCs at late afternoon of proestrus. To examine whether the observed elevation in the MPSC frequency is specific for the time of killing, action of E2 on the mPSCs was investigated in the proestrus morning (proestrus A.M.). Using the same high physiologic dose of E2, we measured the parameters of the mPSCs of GnRH neurons. In contrast to the elevation observed at proestrus P.M., no significant alteration was detected in the mPSC frequency of GnRH neurons (Fig. 2B; Table 3). Amplitude, rise, and decay $\tau$ parameters also showed no change (Table 3).
The effect of E2 treatment on the mPCSs of GnRH neurons was also investigated in brain slices from metestrous mice killed in the late afternoon. Application of the same high physiologic concentration of E2, however, resulted in a significant decrease of mPSC frequency $(80.6 \pm 7.54 \%$ from $1.120 \pm$

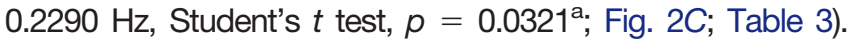
Cumulative probability plots also demonstrate significant differences in the control and the treated intervals (KolmogorovSmirnov, $p=0.0332^{d}$ ). No change was observed in the amplitude, rise, and decay $\tau$, respectively (Table 3).

Comparison of the percentage data on the frequency of mPSCs demonstrated that the effect of E2 at the late 
Table 4. ANOVA+D analysis of percentage changes in frequency, amplitude, rise, and decay $\tau$ of $\mathrm{mPSCs}$, respectively, measured in proestrus pm, proestrus am, and metestrus pm

\begin{tabular}{|c|c|c|c|c|c|}
\hline \multirow{3}{*}{ Frequency } & $F$ & df & $p$ & & $p$ (Dunnett's post hoc test) \\
\hline & 7.9114 & 32 & $0.0017^{\mathrm{b}}$ & Pro pm vs Pro am & $0.034^{\mathrm{b}}$ \\
\hline & & & & Pro pm vs Met pm & $0.0009^{b}$ \\
\hline Amplitude & 0.0539 & 32 & $0.9475^{\mathrm{b}}$ & - & - \\
\hline Rise $\tau$ & 0.2374 & 32 & $0.7901^{b}$ & - & - \\
\hline Decay $\tau$ & 0.0494 & 32 & $0.9518^{b}$ & - & - \\
\hline
\end{tabular}

$\mathrm{df}=$ degree of freedom of ANOVA test of percentage data.

$F=F$ values of ANOVA test of percentage data.

$p=p$ probability values of ANOVA or Dunnett's test of percentage data.

Pro $=$ proestrus; Met $=$ metestrus; $a m=$ morning; $p m=$ afternoon

afternoon of proestrus is significantly different from its action during the proestrus morning and metestrus afternoon (ANOVA $+D, p=0.0017^{\text {b }}$; Fig. $2 D$; Table 4). Percentage data for amplitude, rise, and decay $\tau$ showed no significant differences (Table 4). In addition, MPSC frequencies in the control periods of the three groups presented significant differences (ANOVA+D, $p=0.0146^{\text {b; }}$ Table 5), with the highest frequency in proestrus P.M. (Table 3), suggesting that intensity of the synaptic input to GnRH neurons is the strongest in proestrus P.M. Amplitude, rise, and decay $\tau$ data of the control periods measured in the three groups, however, exhibited no significant differences (Table 5).

\section{The E2-evoked effect on mPSCs utilizes ER $\beta$ and activates nNOS via Src kinase/PI3K/Akt pathway in proestrus P.M.}

To explore elements of the pathway activated by E2 (200 pM) in GnRH neurons in proestrus P.M., first we investigated the subtype and localization of the ER participating in the process. The main ER in $\mathrm{GnRH}$ neurons is the $\beta$-subtype (Hrabovszky et al., 2000, 2001, 2007; Kalló et al., 2001). In addition, the rapid action of E2 (1-2 min after application) on the mPSC frequency suggested the involvement of a non-genomic action. Therefore, the specific ER $\beta$ antagonist PHTPP was applied in the aCSF before E2 $(200 \mathrm{pM})$ administration. The frequency of mPSCs presented no significant alteration (Fig. 3A,F; Table 3), suggesting that indeed $\mathrm{ER} \beta$ was involved in the process. Amplitude, rise, and decay $\tau$ parameters also showed no significant change (Table 3 ).

Although PHTPP is lipophilic, therefore, its diffusion out of the cell cannot be excluded, intracellular administration provides more specific blockade than extracellular appli- cation of this drug. To increase the possibility that $\operatorname{ER} \beta$ present in the recorded GnRH neuron participated in the observed effect of E2, PHTPP was applied intracellularly (intraPHTPP) in the recording patch pipette to block ER $\beta$ mediated processes mostly in the recorded GnRH neuron. Intracellular administration of PHTPP also abolished the action of E2 (Fig. 3B,F; Table 3).

Previous studies have demonstrated (Farkas et al., 2016) that activation of the retrograde NO signaling pathway in the GnRH neurons results in increased mPSC frequency in $\mathrm{GnRH}$ neurons. To test the hypothesis that retrograde NO signaling mediates the effect of $\mathrm{E} 2$ on the synaptic input of the GnRH neurons, CPTIO, an NOscavenger, was applied intracellularly in the recorded $\mathrm{GnRH}$ neuron before adding E2 to the slice. The mPSC measurements revealed that CPTIO fully eliminated action of E2 (Fig. 3C,F; Table 3).

As data from the literature indicate that in other hypothalamic cell types activation of ER $\beta$ may result in phosphorylation of nNOS and thus NO generation via an Src/ PI3K/Akt-dependent manner (Gingerich and Krukoff, 2008), we applied the Src kinase inhibitor PP2 or the PI3K blocker LY294002 intracellularly in the pipette solution, separately. The MPSC measurements demonstrated that both PP2 and LY294002 fully abolished effect of E2 (Fig. 3D-F; Table 3).

Comparison of the effect of E2 in proestrus P.M. with the other five measurement groups involving the above described inhibitors ("Pro pm E2" vs "Pro pm PHTPP+E2," "Pro pm intraPHTPP+E2," "Pro pm CPTIO+E2," "Pro pm PP2+E2," and "Pro pm LY294002+E2," respectively) revealed that the percentage change in frequency in Pro pm E2 differs significantly from each of the other five groups (ANOVA $+\mathrm{D}, p=0.0026^{\mathrm{b}}$; Table 6 ) demonstrating that in-

Table 5. ANOVA+D analysis of frequency, amplitude, rise, and decay $\tau$ values of the control periods of mPSCs, respectively, measured in proestrus pm, proestrus am, and metestrus pm

\begin{tabular}{llllll}
\hline & $F$ & $\mathrm{df}$ & $p$ & & $p$ (Dunnett's post hoc test) \\
Frequency & 4.8850 & 32 & $0.0146^{\mathrm{b}}$ & $\begin{array}{l}\text { Pro pm vs Pro am } \\
\text { Pro pm vs Met pm }\end{array}$ & $0.015^{\mathrm{b}}$ \\
& & & & - & - \\
Amplitude & 2.1160 & 32 & $0.1386^{\mathrm{b}}$ & - & - \\
Rise $\tau$ & 0.7290 & 32 & $0.4907^{\mathrm{b}}$ & - & - \\
Decay $\tau$ & 0.1574 & 32 & $0.8550^{\mathrm{b}}$ & - & - \\
\hline
\end{tabular}

$\mathrm{df}=$ degree of freedom of ANOVA test of percentage data.

$F=F$ values of ANOVA test of percentage data.

$p=p$ probability values of ANOVA or Dunnett's test of percentage data.

Pro = proestrus; Met $=$ metestrus; am = morning; pm = afternoon. 

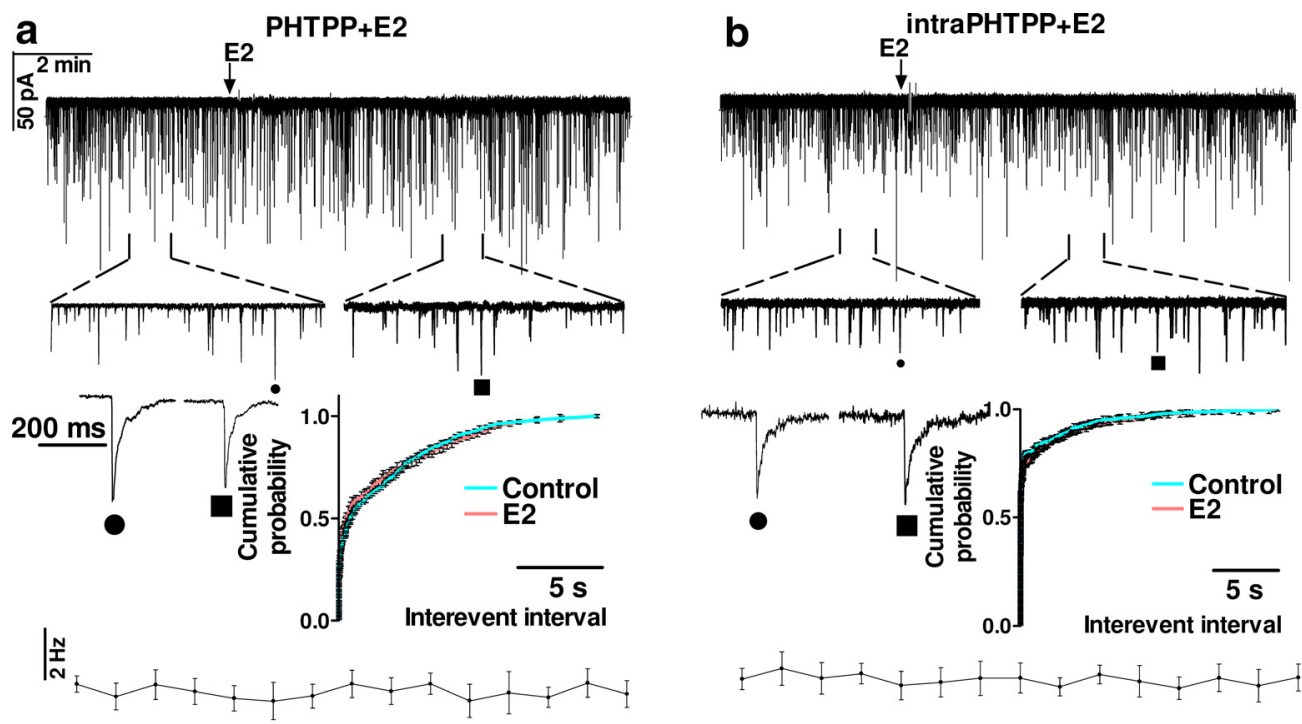

C

CPTIO+E2

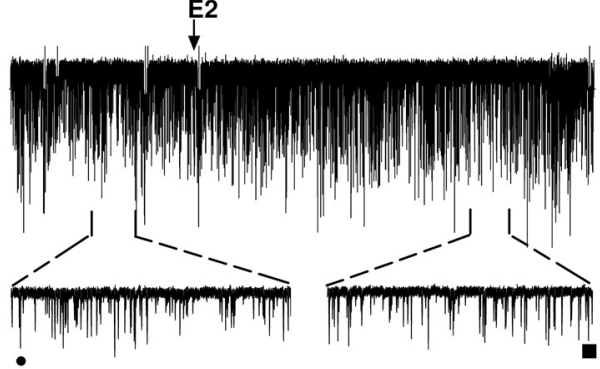

d
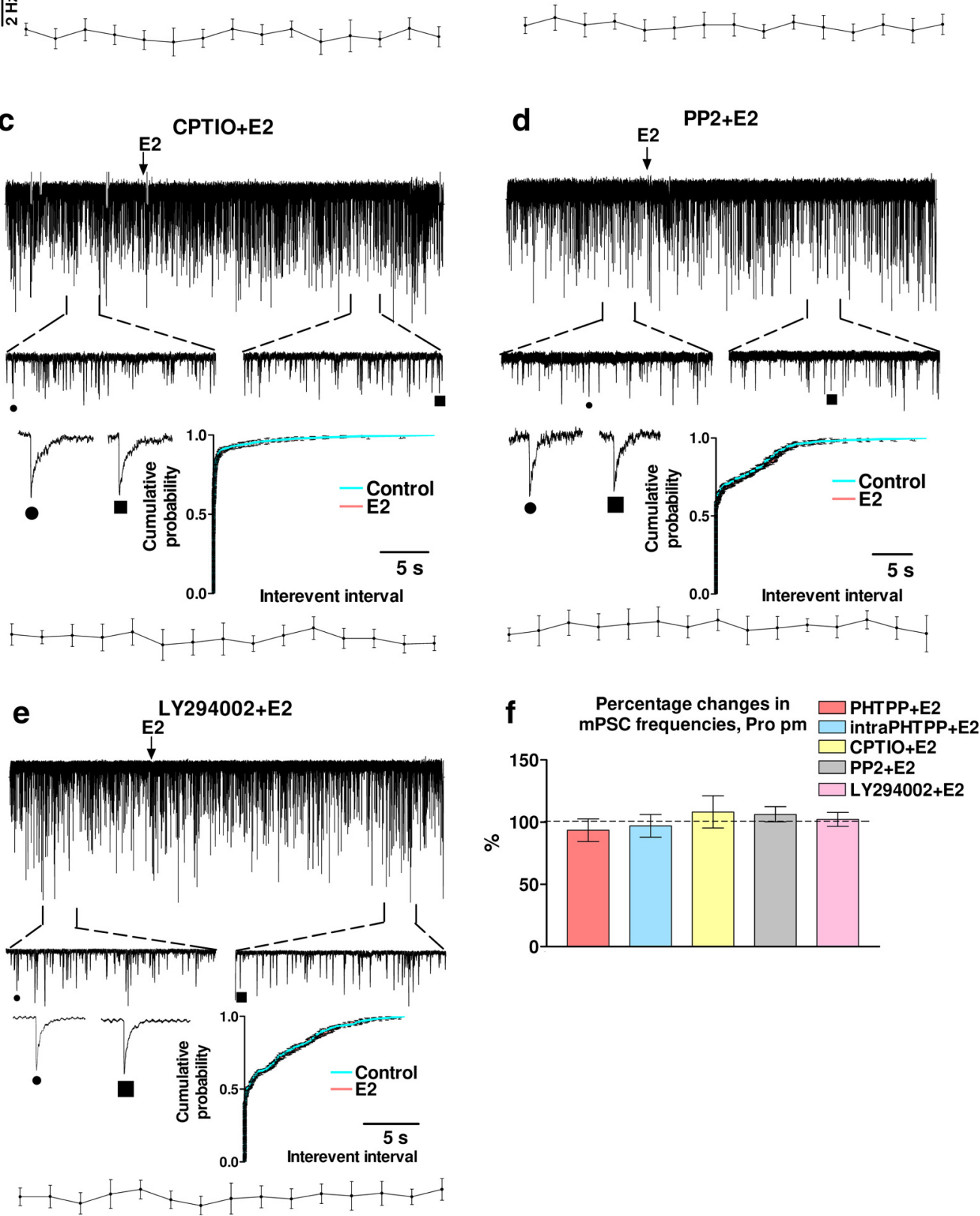

Figure 3. Effects of various blockers on the E2-evoked increase in the frequency of mPSCs in GnRH neurons in proestrus afternoon. 
continued

The ER $\beta$ antagonist, PHTPP eliminated action of E2 in proestrus afternoon independently of whether PHTPP was applied extracellularly $(\boldsymbol{A})$ or intracellularly $(\boldsymbol{B})$. C Intracellular application of the NO-scavenger CPTIO abolished the effect of E2 in proestrus afternoon. $\boldsymbol{D}$, The Src inhibitor PP2 also eliminated the effect of E2. $\boldsymbol{E}$, The PI3K blocker LY294002 also abolished the action of E2. $\boldsymbol{F}$, Bar graph shows that effect of E2 was mediated via ER $\beta$ and the triggered retrograde NO signaling mechanism. The inserts below the 15 min recordings are 1-1 min zoomed periods from the respective recording before and after E2 administration. Individual PSC events are also shown from the control (to indentify in the 1-min zoomed periods, it is tagged by $\bullet$ ) and the E2-treated (tagged by $\mathbf{m}$ ) periods. Time course of the mean frequency and cumulative probabilities of the interevent intervals are presented under each recording.

deed the $\mathrm{ER} \beta / \mathrm{Src} / \mathrm{PI} / 3 \mathrm{~K} / \mathrm{Akt} / \mathrm{nNOS}$-dependent pathway was activated by E2 in proestrus P.M. Analysis has also revealed, that in the 5-min-long control periods Pro pm E2 data (Table 3) did not differ significantly from the other five groups (ANOVA ${ }^{\text {c; }}$ Table 7) showing that none of the applied inhibitors evoked any change by themselves in the basal values of the analyzed parameters during the control periods.

\section{Both GABAergic and glutamatergic inputs are detectable in proestrus P.M.}

In female mice, solely the $\mathrm{GABA}_{A}-\mathrm{R}$ mediated component of the GABAergic transmission is detectable over $\mathrm{GnRH}$ neurons in coronal brain slices during the negative feedback period (Sullivan and Moenter, 2003; Balint et al., 2016). Nevertheless, there is only limited information about the role of GABA and glutamate in the regulation of $\mathrm{GnRH}$ neurons at proestrus P.M. Therefore, blocker of $\mathrm{GABA}_{\mathrm{A}}-\mathrm{R}$ (picrotoxin) and two inhibitors of ionotropic glutamatergic transmission (kynurenic acid, NBQX) were probed in measuring mPSCs in GnRH neurons of brain slice from proestrous P.M. mice. Picrotoxin diminished the frequency of mPSCs but did not eliminate them fully (0-5 min: $1.784 \pm 0.1549 \mathrm{~Hz}$; 5-10 min: $0.831 \pm 0.1211$ $\mathrm{Hz}$; Fig. $4 A$ ), because significant amount of mPSCs remained detectable in seven out of nine $\mathrm{GnRH}$ neurons (from six mice) after blocking the $\mathrm{GABA}_{\mathrm{A}}-\mathrm{Rs}$. Thus, the wide-spectrum ionotropic glutamatergic receptor blocker, kynurenic acid was added to the aCSF in the continuous presence of picrotoxin. Kynurenic acid fully abolished the residual mPSCs (10-15 min: $0.089 \pm 0.0542 \mathrm{~Hz}$; Fig. $4 A$ ), revealing the occurrence of strong glutamatergic neurotransmission beside the GABAergic one in proestrus P.M. Current-voltage relationship (I-V) of the mPSCs re- corded in the presence of picrotoxin confirmed the contribution of ionotropic Glu-Rs because reversal potential of these mPSCs was $5.23 \mathrm{mV}$, which is rather near the calculated value of these glutamatergic ion channels (6.66 $\mathrm{mV}$; Fig. 4B). To determine the subtype of the ionotropic Glu-R involved in the phenomenon, the AMPA/kainate- $R$ blocker NBQX was added into the aCSF in the presence of picrotoxin. NBQX fully eliminated the glutamatergic mPSCs, suggesting involvement of AMPA/kainate-Rs (Fig. 4C).

\section{Both GABAergic and glutamatergic afferents to GnRH neurons express functional sGC receptors for NO signals}

The natural question arises which synaptic input plays role in the NO-mediated elevated frequency of mPSCs observed on E2 application in proestrus P.M. To determine whether NO produced by GnRH neurons may target their incoming GABAergic and glutamatergic afferents via retrograde signaling, the presence of the $\mathrm{NO}$ receptor, sGC was studied in vGAT or vGLUT2-immunoreactive (IR) axon terminals contacting the cell membrane of $\mathrm{GnRH}$ neurons using triple-label immunofluorescence and confocal laser microscopy.

Quantitative analyses of triple-labeled sections showed that double-labeled vGLUT2/sGC axon varicosities contacted $89.58 \pm 4.9 \%$ of the analyzed GnRH-IR neurons $(n$ $=3 ; 68$ neurons) On the surface of the contacted neurons, $33.85 \pm 5.08 \%$ of the vGLUT2 varicosities also contained sGC. Double-labeled vGAT/sGC axon varicosities were observed on the surface of $80.78 \pm 5.55 \% \mathrm{GnRH}-\mathrm{IR}$ neurons ( $n=4 ; 97$ neurons). On the surface of contacted

Table 6. ANOVA+D analysis of the E2-triggered percentage changes in frequency, amplitude, rise, and decay $\tau$ of $\mathrm{mPSCs}$, respectively, measured in proestrus pm, proestrus pm+PHTPP, proestrus pm+intraPHTPP, proestrus pm+CPTIO, proestrus pm+PP2, and proestrus pm+LY294002

\begin{tabular}{|c|c|c|c|c|c|}
\hline & $F$ & $\mathrm{df}$ & $p$ & & $p$ (Dunnett's post hoc test) \\
\hline \multirow[t]{5}{*}{ Frequency } & 4.343 & 50 & $0.0026^{b}$ & Pro pm vs PHTPP & $0.0033^{b}$ \\
\hline & & & & Pro pm vs intraPHTPP & $0.0060^{\mathrm{b}}$ \\
\hline & & & & Pro pm vs CPTIO & $0.0151^{\mathrm{b}}$ \\
\hline & & & & Pro pm vs PP2 & $0.0201^{b}$ \\
\hline & & & & Pro pm vs LY294002 & $0.0103^{b}$ \\
\hline Amplitude & 0.6555 & 50 & $0.6589^{\mathrm{b}}$ & - & - \\
\hline Rise $\tau$ & 0.6889 & 50 & $0.6344^{\mathrm{b}}$ & - & - \\
\hline Decay $\tau$ & 0.8241 & 50 & $0.5392^{b}$ & - & - \\
\hline
\end{tabular}

$\mathrm{df}=$ degree of freedom of ANOVA test of percentage data.

$F=F$ values of ANOVA-test of percentage data.

$p=p$ probability values of ANOVA or Dunnett's test of percentage data.

Pro = proestrus; Met = metestrus; am = morning; pm = afternoon PHTPP = ER $\beta$ antagonist; intraPHTPP = intracellularly applied ER $\beta$ antagonist; CPTIO = NO-scavenger; PP2 = Src kinase inhibitor; LY294002 = PI3K inhibitor. 
Table 7. ANOVA analysis of frequency, amplitude, rise, and decay $\tau$ values of the control periods of MPSCs, respectively, measured in proestrus pm, proestrus pm+PHTPP, proestrus pm+intraPHTPP, proestrus pm+CPTIO, proestrus pm+PP2, and proestrus pm+LY294002

\begin{tabular}{llll}
\hline & $F$ & df & $p$ \\
Frequency & 0.4291 & 50 & $0.8259^{\mathrm{c}}$ \\
Amplitude & 0.3411 & 50 & $0.8852^{\mathrm{c}}$ \\
Rise $\tau$ & 0.1031 & 50 & $0.9910^{\mathrm{C}}$ \\
Decay $\tau$ & 0.3504 & 50 & $0.8793^{\mathrm{C}}$
\end{tabular}

$\mathrm{df}=$ degree of freedom of ANOVA test.

$F=F$ values of ANOVA test.

$p=p$ probability values of ANOVA test.

neurons, $37.95 \pm 2.89 \%$ of the vGAT-IR axons also contained sGC (Fig. 5).

These data indicate that approximately third of the GABAergic and glutamatergic presynaptic afferents of $\mathrm{GnRH}$ neurons are sensitive to NO liberated from $\mathrm{GnRH}$ neurons, thus they may be the final targets of the estradiol-evoked actions.

Presence of the SGC in both GABAergic and glutamatergic terminals contacting $\mathrm{GnRH}$ neurons were further investigated with mPSC measurements. E2 (200 pM) significantly increased the frequency of GABAergic mPSCs in the presence of kynurenic acid (Student's $t$ test, 133.7 $\pm 12.27 \%, p=0.0335^{\text {a }}$; Fig. $\left.6 A, D\right)$, without affecting the amplitude, rise, and decay $\tau$ (Table 3 ). Time course of mean frequency under the recording shows that elevation started in 2-3 min and after reaching a peak it slowly decreased. The significant differences in the control and the treated interevent intervals are also confirmed by the cumulative probability plots (Kolmogorov-Smirnov, $p=$ $\left.0.0121^{\mathrm{d}}\right)$. E2 also elevated the frequency of glutamatergic mPSCs in the presence of picrotoxin (143.1 $\pm 17.23 \%, p$ $=0.0470^{\mathrm{a}}$ ) with a time course similar to the one measured in the presence of kynurenic acid (Fig. 6B,D). The cumulative probabilities provided further evidence for the significant effect of E2 on the glutamatergic mPSCs (Kolmogorov-Smirnov, $p=0.0217^{\mathrm{d}}$ ). No change in amplitude, rise, and decay $\tau$ were detected (Table 3 ). When both inputs were blocked simultaneously, no mPSCs were detected on E2 application (Fig. 6C), suggesting that other neurotransmitter systems were not influenced by the E2 administration. The measurements also showed that frequency (Student's $t$ test, $p=0.0352^{\mathrm{a}}$ ), amplitude $\left(p=0.0001^{\mathrm{a}}\right)$, rise $\left(p=0.0276^{\mathrm{a}}\right)$, and decay $\tau(p=$ $0.0010^{\mathrm{a}}$ ) values of the GABAergic mPSCs were significantly higher than those of glutamatergic ones measured during the control periods (Tables 3,8 ).

\section{Discussion}

The present study provides electrophysiological and structural evidence for the involvement of ER $\beta$ and NO signaling in the mediation of the effect of E2 increasing fast neurotransmission onto $\mathrm{GnRH}$ neurons at late afternoon of proestrus. Accordingly, (1) E2 significantly increases the frequency of mPSCs in GnRH neurons; (2) this direct and rapid effect of $\mathrm{E} 2$ requires $\mathrm{ER} \beta$ signaling in $\mathrm{GnRH}$ neurons; (3) the activation of $\mathrm{ER} \beta$ signaling results in NO production via the Src/PI3K/Akt/nNOS-dependent pathway in GnRH neurons; and (4) the retrograde transmitter NO acts on both glutamatergic and GABAergic boutons conveying facilitatory tone to $\mathrm{GnRH}$ neurons and increases the excitatory fast neurotransmission.

\section{E2 increases frequency of mPSCs in GnRH neurons specifically in proestrus afternoon}

Our present results showed that E2 at high physiologic concentration, which corresponds to the serum E2 level in
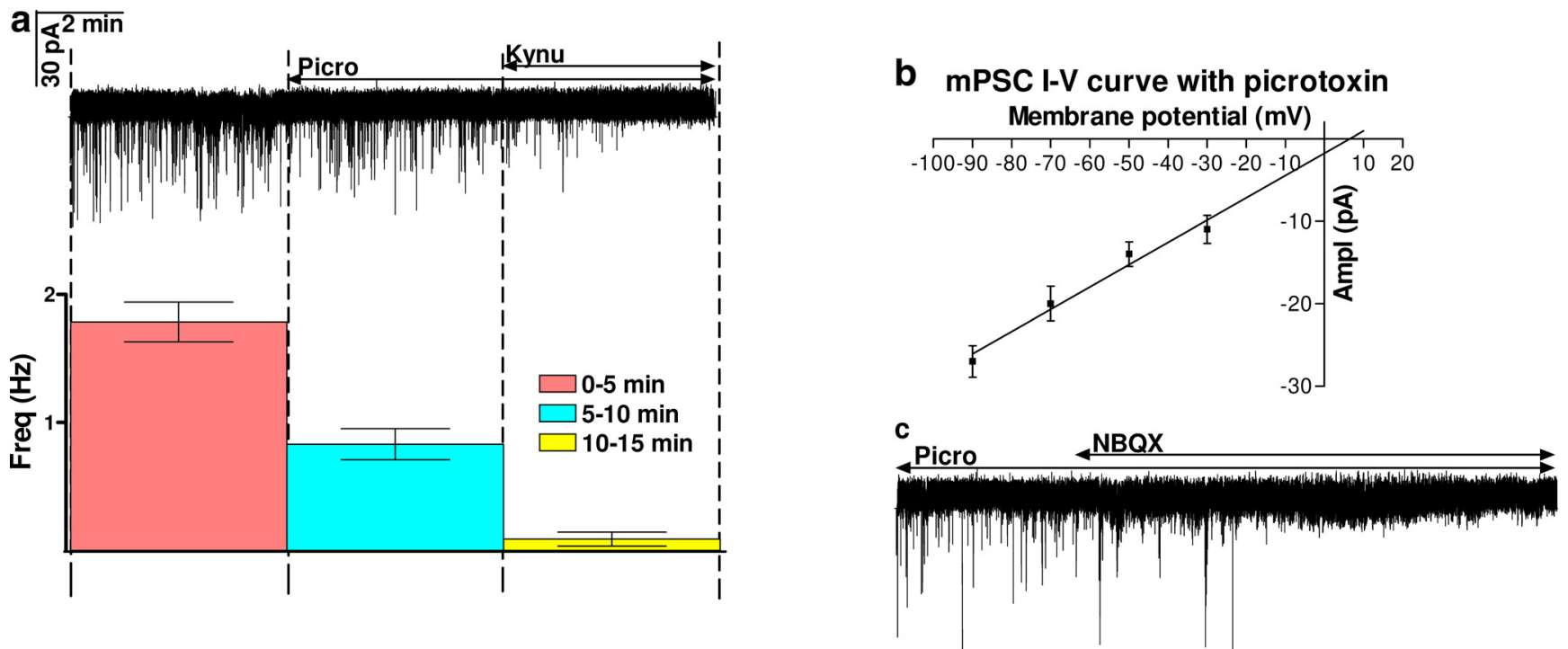

Figure 4. Both GABAergic and glutamatergic inputs are detectable during proestrus afternoon. $\boldsymbol{A}$, Picrotoxin decreased frequency of the mPSCs only partially. The residues were eliminated with the subsequent application of the ionotropic glutamate receptor blocker kynurenic acid. Average frequencies of the respective 5-5 min periods below the recording also showed this phenomenon. $\boldsymbol{B}$, I-V curve shows that reversal potential of the glutamate $\mathrm{mPSCs}(5.23 \mathrm{mV})$ is near the calculated value of that of glutamate channel (6.66 $\mathrm{mV}$ ). $\boldsymbol{C}$, The AMPA/kainate-R inhibitor NBQX also abolished the residual mPSCs. 


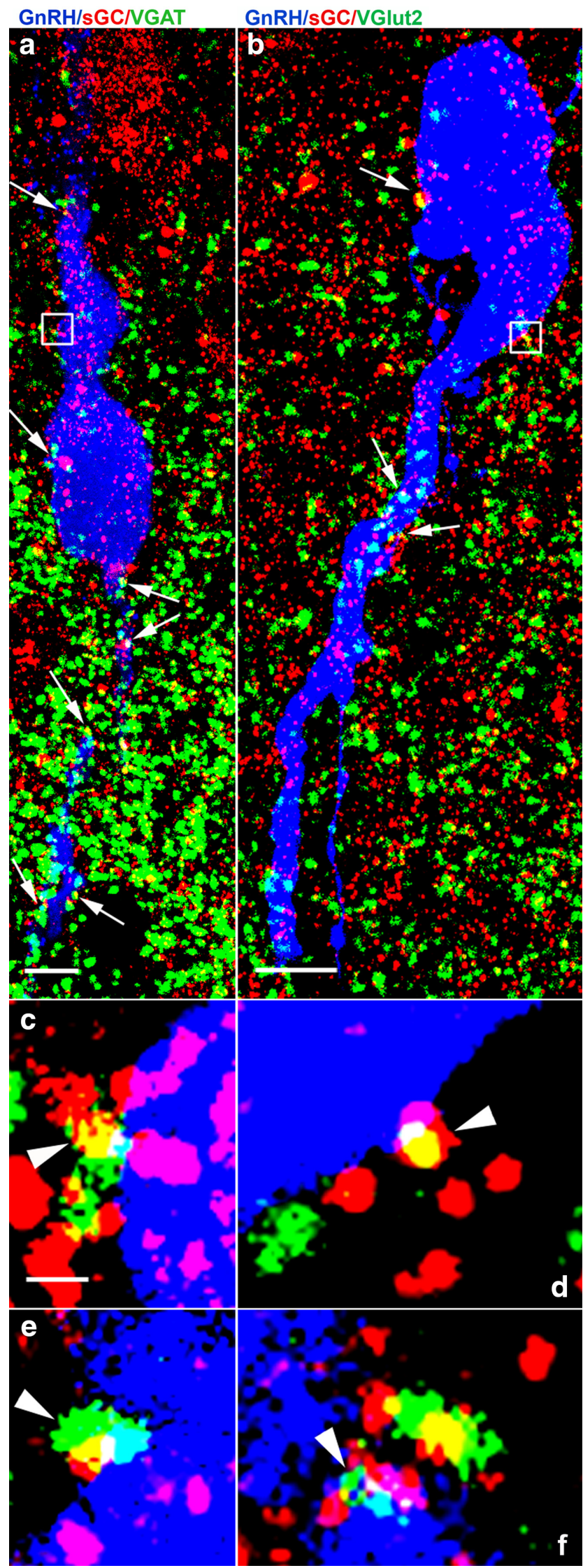

Figure 5. Presence of sGC-immunoreactivity in vGAT- $(a, c, e)$
Figure 5. continued

and vGLUT2-IR ( $\boldsymbol{B}, \boldsymbol{D}, \boldsymbol{F})$ axons contacting $\mathrm{GnRH}$ neurons of mice. Several vGAT-IR (green; $\boldsymbol{A}, \boldsymbol{C}, \boldsymbol{E}$ ), vGLUT2-IR (green; $\boldsymbol{B}, \boldsymbol{D}$, $\boldsymbol{F}$ ), and SGC-IR (red) varicosities establish contact with the cell body and dendrites of GnRH neurons (blue). The yellow color in a population of VGAT-IR or vGLUT2-IR boutons in contact with the plasma membrane of $\mathrm{GnRH}$ neurons (arrows) demonstrates the presence of $\mathrm{sGC}$ in these profiles. The regions labeled with white rectangles are shown at higher power in $\boldsymbol{C}, \boldsymbol{D}$, arrowheads identify double-labeled varicosities. Further cases $(\boldsymbol{E}, \boldsymbol{F})$ for demonstration of the expression of SGC immunoreactivity in vGAT-IR $(\boldsymbol{E})$ and vGLUT2-IR $(\boldsymbol{F})$ axon varicosities abutting $\mathrm{GnRH}$-IR profiles. Scale bar $=5 \mu \mathrm{m}$, optical slice thickness $=0.6 \mu \mathrm{m}$.

proestrus afternoon, elevated mPSC frequency in GnRH neurons at late afternoon stage of proestrus, when the positive estradiol feedback culminates. This result is supported by Romanò et al. (2008), demonstrating an elevated GABAergic mPSC frequency in $\mathrm{GnRH}$ neurons on $\mathrm{E} 2$ treatment. E2 did not increase the frequency of $\mathrm{mP}$ SCs in proestrus morning or metestrus. Rather E2 even decreased the MPSC frequency in metestrus afternoon. This latter result is in good accordance with the literature data showing an E2-triggered attenuation of PSC frequency during metestrus (Balint et al., 2016). In contrast, a very recent paper published by Liu et al. (2017), has claimed that chronic E2 administration has no effect on GABA and glutamate inputs to $\mathrm{GnRH}$ neurons neither in negative nor in positive feedback periods, i.e., PSCs are independent from the stage of the estrous cycle (Liu et al., 2017). The most probable explanation to resolve this discrepancy is that two different experimental paradigms were used. In our model, intact late proestrous mice were studied with intact ovarian signaling mechanisms and physiologic concentration of E2 at the time of killing. The report from Liu et al. (2017) was based on the use of gonadectomized, estradiol replaced animals mimicking both the negative and positive feedback periods. Ovariectomy, in addition to ceasing the natural estradiol signaling, abolishes supply of numerous other indispensable hormones too, such as progesterone, activin, inhibin and anti-Müllerian hormone to the HPG axis including $\mathrm{GnRH}$ neurons (DeFazio and Moenter, 2002; Norwitz et al., 2002; Gregory and Kaiser, 2004; Sun and Moenter, 2010; Wang et al., 2010; Kenealy and Terasawa, 2012; Cimino et al., 2016; Stamatiades and Kaiser, 2017). In addition, the E2 replacement cannot mimic the natural fluctuation of E2 level.

Similar discrepancy exists between our present results revealing that robustly higher MPSC frequency was detected in proestrus P.M. than in proestrus A.M. or metestrus P.M., and those of Liu et al. (2017) finding no difference in the fast neurotransmission to $\mathrm{GnRH}$ neurons in positive versus negative feedback periods. The reason behind these contradictory data could be again the difference between the two models used. Nevertheless, indispensable role of the fast synaptic transmission in the effect of E2 on $\mathrm{GnRH}$ neurons has also been reported, since the E2-evoked changes in $\mathrm{GnRH}$ neuron firing were eliminated by blockade 

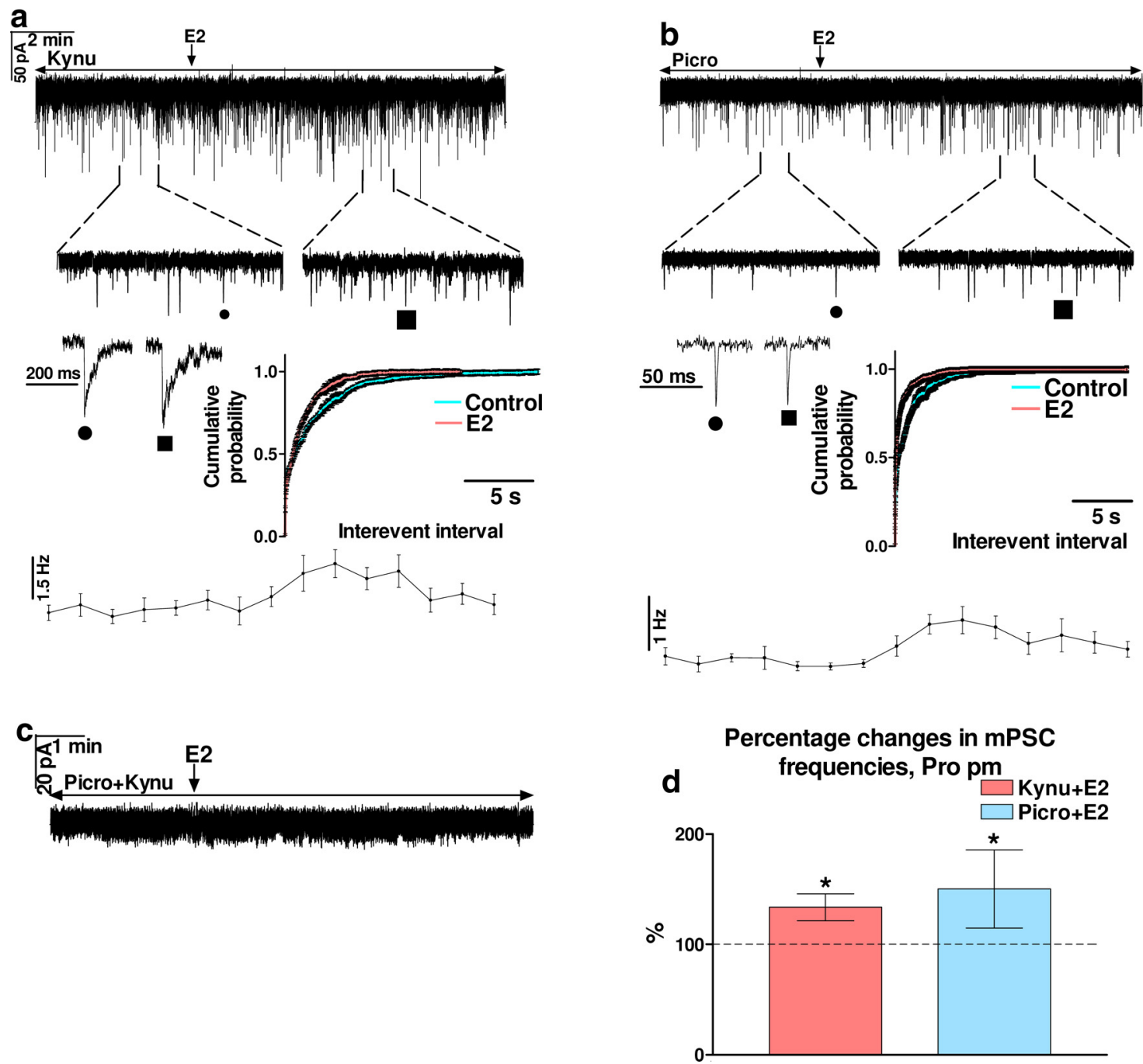

Figure 6. E2 (200 pM) acts on both fast GABAergic and glutamatergic (via AMPA/kainate-R) neurotransmissions to GnRH neurons in proestrus afternoon. $\boldsymbol{A}$, In the presence of kynurenic acid, E2 elevated frequency of the GABAergic mPSCs. $\boldsymbol{B}$, In the presence of picrotoxin, E2 increased frequency of glutamatergic mPSCs, too. $\boldsymbol{C}$, E2 was unable to trigger any mPSCs in the co-presence of picrotoxin and kynurenic acid. $\boldsymbol{D}$, Bar graph reveals that E2 increases frequency of both GABAergic and glutamatergic mPSCs significantly. The inserts below the 15 min recordings are 1-1 min zoomed periods from the respective recording before and after E2 administration. Individual PSC events are shown from the control (to indentify in the 1-min zoomed periods, it is tagged by $\bullet$ ) and the E2-treated (tagged by $\mathbf{-}$ ) periods. Time course of the mean frequency and cumulative probabilities of the interevent intervals are presented under each recording. Picro $=$ picrotoxin, Kynu $=$ kynurenic acid; $* p<0.05$.

of GABAergic and glutamatergic neurotransmission (Christian and Moenter, 2008; Chu et al., 2009), in agreement with our present results.

Earlier studies have demonstrated that kisspeptin neuron populations of the AVPV region and the kisspeptin/ neurokininB/dynorphin (KNDy) neurons of the arcuate nucleus (ARC) mediate the positive and negative feedback actions of E2 toward the GnRH system (Smith et al., 2005; Kalló et al., 2012; Clarkson et al., 2017; Lunenfeld and Buhler, 2017; Vastagh and Liposits, 2017). Human mutations and knock out animals clearly showed the importance of these indirect pathways in the feedback regulation of GnRH neurons (Mayer and Boehm, 2011; Brioude et al., 2013; Ratnasabapathy and Dhillo, 2013; Demirbilek et al., 2015). In contrast, our present data revealed that $\mathrm{GnRH}$ neurons are targets of the direct action of E2 during the positive feedback period. In addition, a very recent paper also demonstrated direct E2 action on mPSCs measured in GnRH neurons during the negative feedback period (Balint et al., 2016). However, these data seems to contradict with the critical importance of the indirect pathways. This discrepancy can be resolved if we hypothesize that the effect of E2 to facilitate the inputs of $\mathrm{GnRH}$ neurons during the afternoon of proestrus amplifies the effects of the indirect pathways that mediate the E2 positive feedback effect, while the inhibitory action of $\mathrm{E} 2$ on the inputs of $\mathrm{GnRH}$ neurons may prevent the influence of these pathways suggesting that the direct and indirect E2 effects work in concert to regulate $\mathrm{GnRH}$ neurons. This idea, however, requires further elucidation. 
Table 8. Student's $t$ test analysis of frequency, amplitude, rise, and decay $\tau$ values of mPSCs, respectively, measured in the presence of picrotoxin (detection of glutamatergic $\mathrm{mP}$ $\mathrm{SCs}$ ) versus kynurenic acid (detection of GABAergic mPSCs)

\begin{tabular}{llll}
\hline & $t$ & $d f$ & $p$ \\
Frequency & 2.373 & 12 & $0.0352^{\mathrm{a}}$ \\
Amplitude & 5.529 & 12 & $0.0001^{\mathrm{a}}$ \\
Rise $\tau$ & 2.506 & 12 & $0.0276^{\mathrm{a}}$ \\
Decay $\tau$ & 4.307 & 12 & $0.0010^{\mathrm{a}}$
\end{tabular}

$\mathrm{df}=$ degree of freedom of Student's $t$ test.

$t=t$ values of $t$ test.

$p=p$ probability values of $t$ test.

\section{The execution of direct, rapid effect of E2 requires} functional ER $\beta$ in $\mathrm{GnRH}$ neurons

It is a well-known fact that GnRH neurons bear ER $\beta$ (Hrabovszky et al., 2000, 2001, 2007). Our present results clearly demonstrated that in proestrus P.M. these neurons responded to E2 via ER $\beta$ because PHTPP, the selective antagonist of this ER subtype, eliminated action of E2 on mPSCs. The intracellular application of this antagonist evoked similar blockade indicating that action of E2 is direct on $E R \beta$ in GnRH neurons. In addition, effect of E2 was rapid, starting in 1-2 min, suggesting a non-genomic action of this hormone. Similar rapid actions of E2 have already been explored in GnRH neurons, suggesting activation of intracellular signaling pathways via membraneassociated ERs (Abrahám et al., 2003; Cheong et al., 2012; Kwakowsky et al., 2014).

\section{Retrograde NO signaling is involved in the E2- triggered increase of mPSC frequency in GnRH neurons}

The present results revealed a key role of the retrograde NO signaling pathway in mediation of the effect of E2 to presynaptic GABAergic and glutamatergic inputs of $\mathrm{GnRH}$ neurons. Presence of the functional nNOS has been recently shown in GnRH neurons, and the release of NO resulted in an elevated GABAergic MPSC frequency in these neurons (Farkas et al., 2016) via the retrograde NO signaling pathway. A very recent paper has also proved the presence of nNOS in GnRH neurons of ewes (Bedenbaugh et al., 2017). In addition, evidence was presented that postsynaptic actions such as binding of glucagonlike peptide- 1 to its receptor in GnRH neurons could activate NO synthesis eventually leading to an increased mPSC frequency via this retrograde pathway (Farkas et al., 2016). In the present work, we found a similar scenario, since binding of E2 to ER $\beta$ could activate nNOS in $\mathrm{GnRH}$ neurons at late proestrus afternoon and the released NO did modulate the release probability of the GABA and glutamate neurotransmission from the afferent terminals. Fundamental role of $\mathrm{NO}$ in the regulation of the hypothalamic centers of reproduction has also been demonstrated in vivo, when L-NAME, a NOS inhibitor was infused into the preoptic region of female mice. The abolishment of NO signaling disrupted the estrous cycle and eventually resulted in infertility (d'Anglemont de Tassigny et al., 2007). Now, we have revealed not only the significance of $\mathrm{NO}$ in the function of $\mathrm{GnRH}$ neurons during positive E2-feedback period, but also showed the involvement of Src kinase and PI3K as crucial elements in the Akt-regulated phosphorylation of nNOS linked to the E2activated ER $\beta$.

It is intriguing that estradiol has completely opposite effects on the inputs of $\mathrm{GnRH}$ neurons during metestrus and proestrus afternoon. While the inhibitory effect is mediated by endocannabinoids during metestrus (Balint et al., 2016), the facilitatory effect is mediated by NO during the afternoon of proestrus. Further studies are needed to understand whether GnRH neurons use different retrograde transmitters in response to E2 during the different phases of the estrous cycle or the sensitivity of the inputs of $\mathrm{GnRH}$ neurons to the different retrograde transmitters is altered by the stages of estrous cycle.

\section{Both GABAergic and glutamatergic neuronal inputs are affected by E2}

Although ionotropic glutamatergic mPSCs have already been demonstrated in GnRH neurons of sagittal slices of the mouse brain (Christian et al., 2009; Liu et al., 2017), these PSCs could have been recorded in $\mathrm{GnRH}$ neurons of acute coronal slices neither from male nor from female mice in negative feedback period, so far (Sullivan and Moenter, 2003; Farkas et al., 2010). In our present work, this excitatory synaptic transmission has been easily detected in the majority of $\mathrm{GnRH}$ neurons suggesting an altered, putatively increased, glutamatergic input to these cells during proestrus. This result partially explains the significantly higher mPSC frequency in proestrus P.M. versus that of in metestrus, described above. Since firing activity and PSC frequency correlate positively (Chu and Moenter, 2005; Christian and Moenter, 2007; Farkas et al., 2013) and firing rate is higher in positive than in negative feedback period (Silveira et al., 2017) these phenomena support further our present data.

It was an intriguing question, which synaptic inputs were affected by the effect of E2. Our present electrophysiological data revealed that both GABAergic and glutamatergic (presumably via AMPA/kainate-R) neurotransmission are influenced by E2 in proestrus P.M. This observation has also been confirmed at the structural level demonstrating the presence of SGC, the receptor of NO, in both types of axon terminals contacting $\mathrm{GnRH}$ neurons. Therefore, the NO released from $\mathrm{GnRH}$ neurons after activation of $\mathrm{ER} \beta$ at late proestrus afternoon can reach both types of terminals and influence the release of GABA and glutamate from them.

Our present results indicate that there is an increased excitatory input to $\mathrm{GnRH}$ neurons in the proestrus afternoon before applying E2. It raises the possibility that this phenomenon is due to the high level of E2 remained in the brain slice after decapitation. The ANOVA analysis of the control period of recordings with various blockers presented in the Table 7, however, demonstrates that these control periods show no significant differences, regardless which inhibitor (ER $\beta$ antagonist or signaling cascade blockers) were applied. Therefore, we suggest that this difference is not due to acute E2 effect, but rather it is a genomic action of E2 that was exerted on $\mathrm{GnRH}$ neurons 


\section{GABAergic terminal}

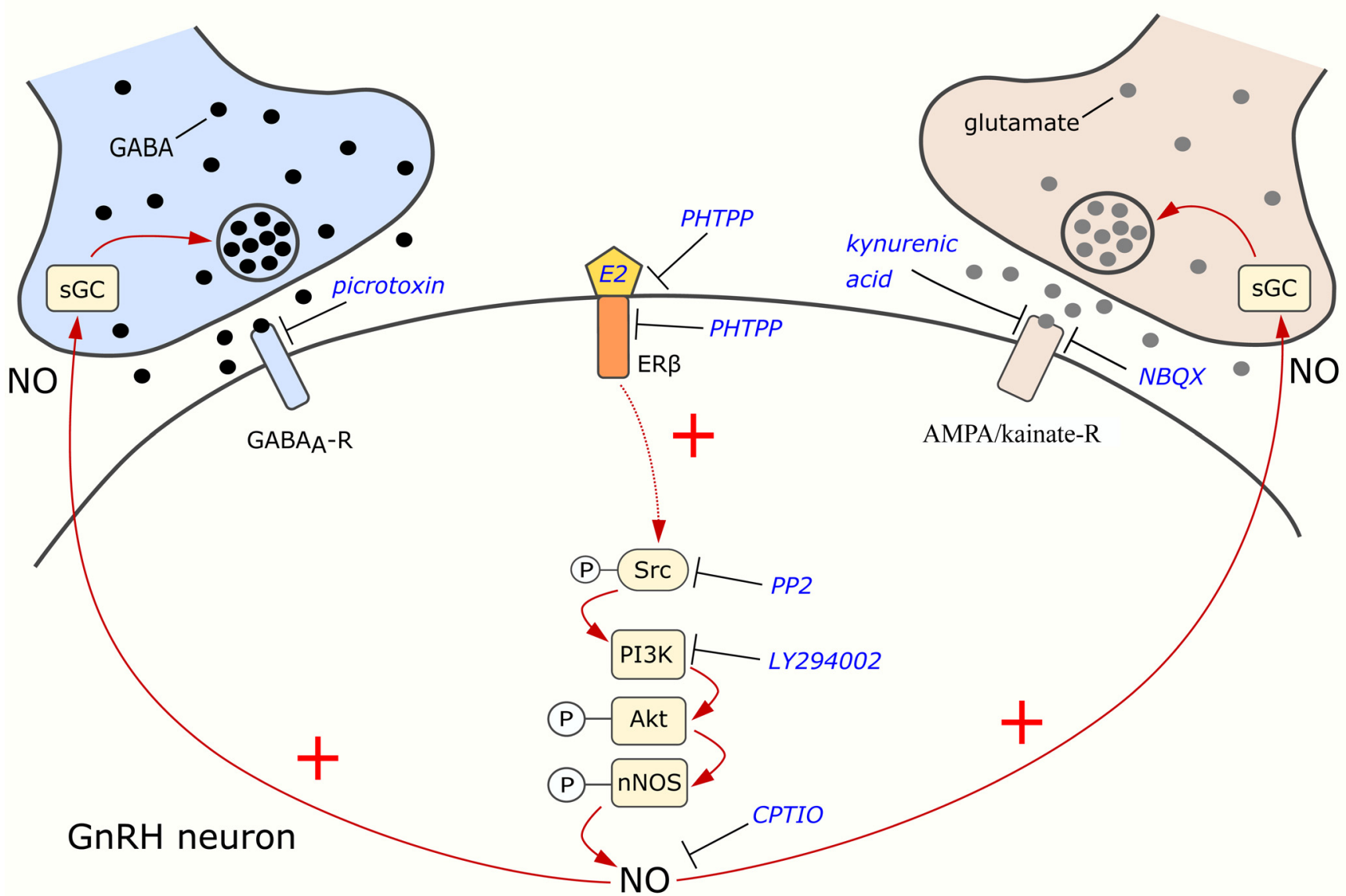

Figure 7. Schematic illustration of E2-ER $\beta$ signaling in GnRH neurons at proestrus afternoon and its proposed action on presynaptic GABA and glutamate release. E2 activates the phosphorylation of neuronal NO synthase (nNOS) via ER $\beta$ and the Src/PI3K/Akt signal transduction pathway resulting in increased NO production. NO then binds to its receptor, sGC, which is present in both GABAergic and glutamatergic afferent boutons of $\mathrm{GnRH}$ neurons. The process increases the release of GABA and glutamate that facilitates the activity of $\mathrm{GnRH}$ neurons via $\mathrm{GABA}_{\mathrm{A}}-\mathrm{R}$ and $\mathrm{AMPA} / \mathrm{kainate}-\mathrm{R}$.

and/or on their inputs before the slice preparation or it is an estrogen independent effect.

To sum up, the proposed model of the rapid E2 action on $\mathrm{GnRH}$ neurons during the positive feedback period is illustrated in Figure 7. This study suggests that E2 binds to $\mathrm{ER} \beta$ and triggers the synthesis and release of NO from $\mathrm{GnRH}$ neurons. Then, using the retrograde NO-signaling pathway, NO binds to SGC located in the presynaptic terminals of GABAergic and glutamatergic afferents, which eventually evokes an increased release of both GABA and glutamate into the synaptic cleft and in turn, excite $\mathrm{GnRH}$ neurons via GABA $\mathrm{A}_{\mathrm{A}}$ and AMPA/kainate receptors making $\mathrm{GnRH}$ neurons more sensitive to the inputs arriving from the AVPV and/or the Arc. The elucidation of the putative participation of the $\mathrm{ER} \beta-\mathrm{NO}$ signaling mechanism in $\mathrm{GnRH}$ neurons of humans during the preovulatory positive E2 feedback action raises a further challenge.

\section{References}

Abrahám IM, Han SK, Todman MG, Korach KS, Herbison AE (2003)

Estrogen receptor beta mediates rapid estrogen actions on gonadotropin-releasing hormone neurons in vivo. J Neurosci 23: 5771-5777. Medline

Adams C, Stroberg W, DeFazio RA, Schnell S, Moenter SM (2018) Gonadotropin-releasing hormone $(\mathrm{GnRH})$ neuron excitability is regulated by estradiol feedback and kisspeptin. J Neurosci 38: 1249-1263. CrossRef Medline

Arimura A, Debeljuk L, Schally AV (1974) Blockade of the preovulatory surge of $\mathrm{LH}$ and $\mathrm{FSH}$ and of ovulation by anti-LH-RH serum in rats. Endocrinology 95:323-325. CrossRef Medline

Balint F, Liposits Z, Farkas I (2016) Estrogen receptor beta and 2-arachidonoylglycerol mediate the suppressive effects of estradiol on frequency of postsynaptic currents in gonadotropinreleasing hormone neurons of metestrous mice: an acute slice electrophysiological study. Front Cell Neurosci 10:77.

Bedenbaugh MN, O'Connell RC, Lopez JA, McCosh RB, Goodman RL, Hileman SM (2018) Kisspeptin, $\mathrm{GnRH}$, and ERalpha colocalise with nNOS neurones in prepubertal female sheep. J Neuroendocrinol 30:e12560. CrossRef

Belchetz PE, Plant TM, Nakai Y, Keogh EJ, Knobil E (1978) Hypophysial responses to continuous and intermittent delivery of hypopthalamic gonadotropin-releasing hormone. Science 202:631633. Medline

Berga S, Naftolin F (2012) Neuroendocrine control of ovulation. Gynecol Endocrinol 28 Suppl 1:9-13. CrossRef Medline 
Bodo C, Kudwa AE, Rissman EF (2006) Both estrogen receptoralpha and -beta are required for sexual differentiation of the anteroventral periventricular area in mice. Endocrinology 147:415420. CrossRef Medline

Brioude F, Bouligand J, Francou B, Fagart J, Roussel R, Viengchareun S, Combettes L, Brailly-Tabard S, Lombes M, Young J, Guiochon-Mantel A (2013) Two families with normosmic congenital hypogonadotropic hypogonadism and biallelic mutations in KISS1R (KISS1 receptor): clinical evaluation and molecular characterization of a novel mutation. PLoS One 8:e53896.

Byers SL, Wiles MV, Dunn SL, Taft RA (2012) Mouse estrous cycle identification tool and images. PLoS One 7:e35538.

Caligioni CS (2009) Assessing reproductive status/stages in mice. Curr Protoc Neurosci Appendix 4:Appendix 4I. CrossRef Medline

Caraty A, Evans NP, Fabre-Nys CJ, Karsch EJ (1995) The preovulatory gonadotrophin-releasing hormone surge: a neuroendocrine signal for ovulation. J Reprod Fertil Suppl 49:245-255. Medline

Chakraborty TR, Rajendren G, Gore AC (2005) Expression of estrogen receptor $\alpha$ in the anteroventral periventricular nucleus of hypogonadal mice. Exp Biol Med (Maywood) 230:49-56. Medline

Chassard D, Bur I, Poirel VJ, Mendoza J, Simonneaux V (2015) Evidence for a putative circadian Kiss-clock in the hypothalamic AVPV in female mice. Endocrinology 156:2999-3011. CrossRef Medline

Cheong RY, Kwakowsky A, Barad Z, Porteous R, Herbison AE, Abrahám IM (2012) Estradiol acts directly and indirectly on multiple signaling pathways to phosphorylate cAMP-response element binding protein in GnRH neurons. Endocrinology 153:3792-3803. CrossRef Medline

Cheong RY, Czieselsky K, Porteous R, Herbison AE (2015) Expression of ESR1 in glutamatergic and GABAergic neurons is essential for normal puberty onset, estrogen feedback, and fertility in female mice. J Neurosci 35:14533-14543. CrossRef Medline

Christian CA, Mobley JL, Moenter SM (2005) Diurnal and estradioldependent changes in gonadotropin-releasing hormone neuron firing activity. Proc Natl Acad Sci USA 102:15682-15687. CrossRef Medline

Christian CA, Moenter SM (2007) Estradiol induces diurnal shifts in GABA transmission to gonadotropin-releasing hormone neurons to provide a neural signal for ovulation. J Neurosci 27:1913-1921. CrossRef Medline

Christian CA, Moenter SM (2008) Critical roles for fast synaptic transmission in mediating estradiol negative and positive feedback in the neural control of ovulation. Endocrinology 149:5500-5508. CrossRef Medline

Christian CA, Moenter SM (2010) The neurobiology of preovulatory and estradiol-induced gonadotropin-releasing hormone surges. Endocr Rev 31:544-577. CrossRef Medline

Christian CA, Pielecka-Fortuna J, Moenter SM (2009) Estradiol suppresses glutamatergic transmission to gonadotropin-releasing hormone neurons in a model of negative feedback in mice. Biol Reprod 80:1128-1135. CrossRef

Chu Z, Moenter SM (2005) Endogenous activation of metabotropic glutamate receptors modulates GABAergic transmission to gonadotropin-releasing hormone neurons and alters their firing rate: a possible local feedback circuit. J Neurosci 25:5740-5749. CrossRef Medline

Chu Z, Andrade J, Shupnik MA, Moenter SM (2009) Differential regulation of gonadotropin-releasing hormone neuron activity and membrane properties by acutely applied estradiol: dependence on dose and estrogen receptor subtype. J Neurosci 29:5616-5627. CrossRef Medline

Cimino I, Casoni F, Liu X, Messina A, Parkash J, Jamin SP, CatteauJonard S, Collier F, Baroncini M, Dewailly D, Pigny P, Prescott M, Campbell R, Herbison AE, Prevot V, Giacobini P (2016) Novel role for anti-Mullerian hormone in the regulation of $\mathrm{GnRH}$ neuron excitability and hormone secretion. Nat Commun 7:10055.

Clarke IJ, Thomas GB, Yao B, Cummins JT (1987) GnRH secretion throughout the ovine estrous cycle. Neuroendocrinology 46:8288. CrossRef Medline
Clarkson J, Han SY, Piet R, McLennan T, Kane GM, Ng J, Porteous RW, Kim JS, Colledge WH, Iremonger KJ, Herbison AE (2017) Definition of the hypothalamic GnRH pulse generator in mice. Proc Natl Acad Sci USA 114:E10216-E10223. CrossRef Medline

Couzinet B, Schaison G (1993) The control of gonadotrophin secretion by ovarian steroids. Hum Reprod 8:97-101. Medline

d'Anglemont de Tassigny X, Campagne C, Dehouck B, Leroy D, Holstein GR, Beauvillain JC, Buée-Scherrer V, Prevot V (2007) Coupling of neuronal nitric oxide synthase to NMDA receptors via postsynaptic density-95 depends on estrogen and contributes to the central control of adult female reproduction. J Neurosci 27: 6103-6114. CrossRef Medline

DeFazio RA, Moenter SM (2002) Estradiol feedback alters potassium currents and firing properties of gonadotropin-releasing hormone neurons. Mol Endocrinol 16:2255-2265. CrossRef Medline

DeFazio RA, Heger S, Ojeda SR, Moenter SM (2002) Activation of A-type gamma-aminobutyric acid receptors excites gonadotropinreleasing hormone neurons. Mol Endocrinol 16:2872-2891. CrossRef Medline

Demirbilek H, Ozbek MN, Demir K, Kotan LD, Cesur Y, Dogan M, Temiz F, Mengen E, Gurbuz F, Yuksel B, Topaloglu AK (2015) Normosmic idiopathic hypogonadotropic hypogonadism due to a novel homozygous nonsense c.C969A (p.Y323X) mutation in the KISS1R gene in three unrelated families. Clin Endocrinol 82:429438. CrossRef Medline

Dubois SL, Acosta-Martínez M, DeJoseph MR, Wolfe A, Radovick S, Boehm U, Urban JH, Levine JE (2015) Positive, but not negative feedback actions of estradiol in adult female mice require estrogen receptor $\alpha$ in kisspeptin neurons. Endocrinology 156:1111-1120. CrossRef

Dungan Lemko HM, Naderi R, Adjan V, Jennes LH, Navarro VM, Clifton DK, Steiner RA (2010) Interactions between neurotensin and $\mathrm{GnRH}$ neurons in the positive feedback control of $\mathrm{GnRH} / \mathrm{LH}$ secretion in the mouse. Am J Physiol Endocrinol Metab 298:E80E88. CrossRef Medline

Farkas I, Kalló I, Deli L, Vida B, Hrabovszky E, Fekete C, Moenter SM, Watanabe M, Liposits Z (2010) Retrograde endocannabinoid signaling reduces GABAergic synaptic transmission to gonadotropinreleasing hormone neurons. Endocrinology 151:5818-5829. CrossRef Medline

Farkas I, Vastagh C, Sárvári M, Liposits Z (2013) Ghrelin decreases firing activity of gonadotropin-releasing hormone $(\mathrm{GnRH})$ neurons in an estrous cycle and endocannabinoid signaling dependent manner. PLoS One 8:e78178.

Farkas I, Vastagh C, Farkas E, Balint F, Skrapits K, Hrabovszky E, Fekete C, Liposits Z (2016) Glucagon-like peptide-1 excites firing and increases GABAergic miniature postsynaptic currents (mP$\mathrm{SCs}$ ) in gonadotropin-releasing hormone $(\mathrm{GnRH})$ neurons of the male mice via activation of nitric oxide (NO) and suppression of endocannabinoid signaling pathways. Front Cell Neurosci 10:214.

Freeman M (1994) The neuroendocrine control of the ovarian cycle of the rat. In: Physiology of reproduction, Ed 2 (Knobil E, Neill J, eds), p 620. New York: Raven Press.

Freeman M (2006) The neuroendocrine control of the ovarian cycle of the rat. In: Knobil and Neill's physiology of reproduction, Ed 3 (Neill J, Plant T, Pfaff D, Challis J, de Kretser D, Richards J, Wassarman $\mathrm{P}$, eds), pp 2327-2388. Cambridge, MA: Academic Press.

Gingerich S, Krukoff TL (2008) Activation of ERbeta increases levels of phosphorylated nNOS and NO production through a Src/PI3K/ Akt-dependent pathway in hypothalamic neurons. Neuropharmacology 55:878-885. CrossRef Medline

Gore AC (2001) Gonadotropin-releasing hormone neurons, NMDA receptors, and their regulation by steroid hormones across the reproductive life cycle. Brain Res Brain Res Rev 37:235-248. Medline

Gregory SJ, Kaiser UB (2004) Regulation of gonadotropins by inhibin and activin. Semin Reprod Med 22:253-267. CrossRef Medline

Grishin AA, Benquet P, Gerber U (2005) Muscarinic receptor stimulation reduces NMDA responses in CA3 hippocampal pyramidal 
cells via $\mathrm{Ca} 2+-$ dependent activation of tyrosine phosphatase. Neuropharmacology 49:328-337. CrossRef Medline

Herbison AE, Moenter SM (2011) Depolarising and hyperpolarising actions of GABA(A) receptor activation on gonadotrophinreleasing hormone neurones: towards an emerging consensus. $J$ Neuroendocrinol 23:557-569. CrossRef Medline

Hrabovszky E, Shughrue PJ, Merchenthaler I, Hajszán T, Carpenter CD, Liposits Z, Petersen SL (2000) Detection of estrogen receptorbeta messenger ribonucleic acid and $125 \mathrm{I}$-estrogen binding sites in luteinizing hormone-releasing hormone neurons of the rat brain. Endocrinology 141:3506-3509. CrossRef Medline

Hrabovszky E, Steinhauser A, Barabás K, Shughrue PJ, Petersen SL, Merchenthaler I, Liposits Z (2001) Estrogen receptor-beta immunoreactivity in luteinizing hormone-releasing hormone neurons of the rat brain. Endocrinology 142:3261-3264. CrossRef Medline

Hrabovszky E, Kalló I, Szlávik N, Keller E, Merchenthaler I, Liposits Z (2007) Gonadotropin-releasing hormone neurons express estrogen receptor-beta. J Clin Endocrinol Metab 92:2827-2830. CrossRef Medline

Hrabovszky E, Molnar CS, Sipos MT, Vida B, Ciofi P, Borsay BA, Sarkadi L, Herczeg L, Bloom SR, Ghatei MA, Dhillo WS, Kallo I, Liposits Z (2011) Sexual dimorphism of kisspeptin and neurokinin $B$ immunoreactive neurons in the infundibular nucleus of aged men and women. Front Endocrinol (Lausanne) 2:80.

Hrabovszky E, Molnár CS, Nagy R, Vida B, Borsay BA, Rácz K, Herczeg L, Watanabe M, Kalló I, Liposits Z (2012a) Glutamatergic and GABAergic innervation of human gonadotropin-releasing hormone-I neurons. Endocrinology 153:2766-2776. CrossRef

Hrabovszky E, Sipos MT, Molnár CS, Ciofi P, Borsay BA, Gergely P, Herczeg L, Bloom SR, Ghatei MA, Dhillo WS, Liposits Z (2012b) Low degree of overlap between kisspeptin, neurokinin $B$, and dynorphin immunoreactivities in the infundibular nucleus of young male human subjects challenges the KNDy neuron concept. Endocrinology 153:4978-4989. CrossRef

Ide S, Hara T, Ohno A, Tamano R, Koseki K, Naka T, Maruyama C, Kaneda K, Yoshioka M, Minami M (2013) Opposing roles of corticotropin-releasing factor and neuropeptide $Y$ within the dorsolateral bed nucleus of the stria terminalis in the negative affective component of pain in rats. J Neurosci 33:5881-5894. CrossRef Medline

Kajta M, Rzemieniec J, Litwa E, Lason W, Lenartowicz M, Krzeptowski W, Wojtowicz AK (2013) The key involvement of estrogen receptor $\beta$ and G-protein-coupled receptor 30 in the neuroprotective action of daidzein. Neuroscience 238:345-360. CrossRef Medline

Kalló I, Butler JA, Barkovics-Kalló M, Goubillon ML, Coen CW (2001) Oestrogen receptor beta-immunoreactivity in gonadotropin releasing hormone-expressing neurones: regulation by oestrogen. $\mathrm{J}$ Neuroendocrinol 13:741-748. Medline

Kalló I, Vida B, Deli L, Molnár CS, Hrabovszky E, Caraty A, Ciofi P, Coen CW, Liposits Z (2012) Co-localisation of kisspeptin with galanin or neurokinin B in afferents to mouse GnRH neurones. J Neuroendocrinol 24:464-476. CrossRef Medline

Kenealy BP, Terasawa E (2012) Rapid direct action of estradiol in $\mathrm{GnRH}$ neurons: findings and implications. Front Endocrinol (Lausanne) 2:106. CrossRef

Keshavarzi S, Power JM, Albers EH, Sullivan RK, Sah P (2015) Dendritic organization of olfactory inputs to medial amygdala neurons. J Neurosci 35:13020-13028. CrossRef Medline

Knobil E (1988) The neuroendocrine control of ovulation. Hum Reprod 3:469-472. Medline

Kwakowsky A, Herbison AE, Abrahám IM (2012) The role of cAMP response element-binding protein in estrogen negative feedback control of gonadotropin-releasing hormone neurons. J Neurosci 32:11309-11317. CrossRef Medline

Kwakowsky A, Cheong RY, Herbison AE, Abrahám IM (2014) Nonclassical effects of estradiol on cAMP responsive element binding protein phosphorylation in gonadotropin-releasing hormone neurons: mechanisms and role. Front Neuroendocrinol 35:31-41. CrossRef Medline
Lin KC, Sun MJ (2005) Relationship between sex hormone-binding globulin and pregnancy outcome in women undergoing controlled ovarian hyperstimulation for assisted reproduction. Endocr J 52: 407-412. Medline

Liu X, Herbison AE (2013) Dopamine regulation of gonadotropinreleasing hormone neuron excitability in male and female mice. Endocrinology 154:340-350. CrossRef Medline

Liu X, Porteous R, Herbison AE (2017) Dynamics of GnRH neuron ionotropic GABA and glutamate synaptic receptors are unchanged during estrogen positive and negative feedback in female mice. eNeuro 4. CrossRef

Lo FS, Erzurumlu RS, Powell EM (2016) Insulin-independent GABAA receptor-mediated response in the barrel cortex of mice with impaired met activity. J Neurosci 36:3691-3697. CrossRef Medline

Lunenfeld B, Buhler K (2017) The neuro control of the ovarain cycle - a hypothesis. Gynecol Endocrinol 1-5.

Makara JK, Katona I, Nyíri G, Németh B, Ledent C, Watanabe M, de Vente J, Freund TF, Hájos N (2007) Involvement of nitric oxide in depolarization-induced suppression of inhibition in hippocampal pyramidal cells during activation of cholinergic receptors. J Neurosci 27:10211-10222. CrossRef Medline

Mayer C, Boehm U (2011) Female reproductive maturation in the absence of kisspeptin/GPR54 signaling. Nat Neurosci 14:704710. CrossRef Medline

Mironov SL, Langohr K (2007) Modulation of synaptic and channel activities in the respiratory network of the mice by NO/cGMP signalling pathways. Brain Res 1130:73-82. CrossRef Medline

Mittelman-Smith MA, Krajewski-Hall SJ, McMullen NT, Rance NE (2016) Ablation of KNDy neurons results in hypogonadotropic hypogonadism and amplifies the steroid-induced LH surge in female rats. Endocrinology 157:2015-2027. CrossRef Medline

Moenter SM (2010) Identified GnRH neuron electrophysiology: a decade of study. Brain Res 1364:10-24. CrossRef Medline

Moenter SM, DeFazio RA (2005) Endogenous gamma-aminobutyric acid can excite gonadotropin-releasing hormone neurons. Endocrinology 146:5374-5379. CrossRef Medline

Moenter SM, Caraty A, Karsch FJ (1990) The estradiol-induced surge of gonadotropin-releasing hormone in the ewe. Endocrinology 127:1375-1384. CrossRef Medline

Moenter SM, Chu Z, Christian CA (2009) Neurobiological mechanisms underlying oestradiol negative and positive feedback regulation of gonadotrophin-releasing hormone neurones. J Neuroendocrinol 21:327-333. CrossRef Medline

Nelson JF, Felicio LS, Randall PK, Sims C, Finch CE (1982) A longitudinal study of estrous cyclicity in aging C57BL/6J mice: I. Cycle frequency, length and vaginal cytology. Biol Reprod 27:327339. Medline

Nelson JF, Felicio LS, Osterburg HH, Finch CE (1992) Differential contributions of ovarian and extraovarian factors to age-related reductions in plasma estradiol and progesterone during the estrous cycle of C57BL/6J mice. Endocrinology 130:805-810. CrossRef Medline

Norwitz ER, Xu S, Xu J, Spiryda LB, Park JS, Jeong KH, McGee EA, Kaiser UB (2002) Direct binding of AP-1 (Fos/Jun) proteins to a SMAD binding element facilitates both gonadotropin-releasing hormone $(\mathrm{GnRH})$ - and activin-mediated transcriptional activation of the mouse GnRH receptor gene. J Biol Chem 277:3746937478. CrossRef

Ottem EN, Godwin JG, Krishnan S, Petersen SL (2004) Dualphenotype GABA/glutamate neurons in adult preoptic area: sexual dimorphism and function. J Neurosci 24:8097-8105. CrossRef Medline

Popa SM, Clifton DK, Steiner RA (2008) The role of kisspeptins and GPR54 in the neuroendocrine regulation of reproduction. Annu Rev Physiol 70:213-238. CrossRef Medline

Porteous R, Petersen SL, Yeo SH, Bhattarai JP, Ciofi P, de Tassigny XD, Colledge WH, Caraty A, Herbison AE (2011) Kisspeptin neurons co-express met-enkephalin and galanin in the rostral periventricular region of the female mouse hypothalamus. J Comp Neur 519:3456-3469. CrossRef Medline 
Radovick S, Levine JE, Wolfe A (2012) Estrogenic regulation of the $\mathrm{GnRH}$ neuron. Front Endocrinol (Lausanne) 3:52.

Ratnasabapathy R, Dhillo WS (2013) The effects of kisspeptin in human reproductive function - therapeutic implications. Curr Drug Targets 14:365-371. Medline

Romanò N, Lee K, Abrahám IM, Jasoni CL, Herbison AE (2008) Nonclassical estrogen modulation of presynaptic GABA terminals modulates calcium dynamics in gonadotropin-releasing hormone neurons. Endocrinology 149:5335-5344. CrossRef Medline

Saleh MC, Connell BJ, Saleh TM (2013) Resveratrol induced neuroprotection is mediated via both estrogen receptor subtypes, $\mathrm{ER}(\alpha)$ and $\operatorname{ER}(\beta)$. Neurosci Lett 548:217-221. CrossRef Medline

Seidl AH, Rubel EW, Barría A (2014) Differential conduction velocity regulation in ipsilateral and contralateral collaterals innervating brainstem coincidence detector neurons. J Neurosci 34:49144919. CrossRef Medline

Silveira MA, Burger LL, DeFazio RA, Wagenmaker ER, Moenter SM (2017) $\mathrm{GnRH}$ neuron activity and pituitary response in estradiolinduced vs proestrous luteinizing hormone surges in female mice. Endocrinology 158:356-366. CrossRef Medline

Smith JT, Cunningham MJ, Rissman EF, Clifton DK, Steiner RA (2005) Regulation of Kiss1 gene expression in the brain of the female mouse. Endocrinology 146:3686-3692. CrossRef Medline

Smith JT, Clifton DK, Steiner RA (2006) Regulation of the neuroendocrine reproductive axis by kisspeptin-GPR54 signaling. Reproduction 131:623-630. CrossRef Medline

Spergel DJ, Krüth U, Hanley DF, Sprengel R, Seeburg PH (1999) GABA- and glutamate-activated channels in green fluorescent protein-tagged gonadotropin-releasing hormone neurons in transgenic mice. J Neurosci 19:2037-2050. CrossRef

Stamatiades GA, Kaiser UB (2017) Gonadotropin regulation by pulsatile GnRH: signaling and gene expression. Mol Cell Endocrinol 463:131-141.

Sullivan SD, Moenter SM (2003) Neurosteroids alter gammaaminobutyric acid postsynaptic currents in gonadotropin-releasing hormone neurons: a possible mechanism for direct steroidal control. Endocrinology 144:4366-4375. CrossRef Medline

Sun J, Moenter SM (2010) Progesterone treatment inhibits and dihydrotestosterone (DHT) treatment potentiates voltage-gated calcium currents in gonadotropin-releasing hormone $(\mathrm{GnRH})$ neurons. Endocrinology 151:5349-5358. CrossRef Medline

Suter KJ, Song WJ, Sampson TL, Wuarin JP, Saunders JT, Dudek FE, Moenter SM (2000) Genetic targeting of green fluorescent protein to gonadotropin-releasing hormone neurons: characterization of whole-cell electrophysiological properties and morphology. Endocrinology 141:412-419. CrossRef Medline

Szabadits E, Cserép C, Ludányi A, Katona I, Gracia-Llanes J, Freund TF, Nyíri G (2007) Hippocampal GABAergic synapses possess the molecular machinery for retrograde nitric oxide signaling. J Neurosci 27:8101-8111. CrossRef Medline

Vastagh C, Liposits Z (2017) Impact of proestrus on gene expression in the medial preoptic area of mice. Front Cell Neurosci 11:183.

Wang L, DeFazio RA, Moenter SM (2016) Excitability and burst generation of AVPV kisspeptin neurons are regulated by the estrous cycle via multiple conductances modulated by estradiol action. eNeuro 3.

Wang Y, Garro M, Kuehl-Kovarik MC (2010) Estradiol attenuates multiple tetrodotoxin-sensitive sodium currents in isolated gonadotropin-releasing hormone neurons. Brain Res 1345:137145. CrossRef Medline

Zhang L, Kolaj M, Renaud LP (2016) Endocannabinoid 2-AG and intracellular cannabinoid receptors modulate a low-threshold calcium spike-induced slow depolarizing afterpotential in rat thalamic paraventricular nucleus neurons. Neuroscience 322:308-319. CrossRef Medline

Zheng F, Lammert K, Nixdorf-Bergweiler BE, Steigerwald F, Volkmann J, Alzheimer C (2011) Axonal failure during high frequency stimulation of rat subthalamic nucleus. J Physiol 589:2781-2793. CrossRef Medline 